\title{
Review
}

\section{Underestimated cyanobacterial diversity: trends and perspectives of research in tropical environments}

\author{
Petr DvořáK ${ }^{1}$, Petr HaŠLER ${ }^{1}$, Dale A. CASAMATTA ${ }^{2 *} \&$ Aloisie PoulíčKová $^{1}$ \\ ${ }^{1}$ Department of Botany, Faculty of Science, Palacký University in Olomouc, Šlechtelu 27, CZ-783 71 Olomouc, \\ Czech Republic \\ ${ }^{2}$ University of North Florida, Department of Biology, University of North Florida, Jacksonville, Florida, USA; \\ "Corresponding author: dcasamat@unf.edu
}

\begin{abstract}
Cyanobacteria are photo-oxygenic prokaryotes present in nearly all ecosystems, where they are important in global oxygen, carbon, and nitrogen cycles. They are often recognized as the harbingers of eutrophication in freshwater systems and are increasingly being noted as nuisance species in marine ecosystems such as coral reefs. In recent years, cyanobacteria have been intensely studied due to their toxicity, harmful bloom formation, and because their distribution and abundance are expected to increase with climate change. Nevertheless, for all of their importance, many gaps in our knowledge of cyanobacteria remain: the distribution, dispersal, and biogeography of these microorganisms are still not understood. Until 1994 little attention was paid to tropical cyanobacteria and their diversity, despite some harmful invasive species having their putative origins in tropical habitats. However, more practiced articulation and research has recently uncovered previously undescribed biodiversity, and in turn changed our knowledge of the evolutionary relationships within the Cyanobacteria. The purpose of this paper is to describe the challenges of working with the cyanobacteria and to review what we know of them from tropical habitats.
\end{abstract}

Key words: cyanobacteria, diversity, tropical environment, biogeography, new genera

\section{INTRODUCTION}

Cyanobacteria are a diverse group of photo-oxygenic bacteria that contain chlorophyll $a$ and are found in myriad habitats. Amongst the oldest known bacterial lineages, fossil records date back to 3.5 BYA (SCHOPF 2000). The most recent study based on a combination of genetics and fossil evidence suggest their origin to mid-Archean, long before the Great Oxidation Event (2.5-2.3 Ga), with multicellularity evolving towards the end of the Archean (SchirrmeIsTER et al. 2015). The earliest lineages of cyanobacteria likely inhabited the benthos of freshwater ecosystems (UYEDA et al. 2016). Cyanobacteria are common components of nearly all ecosystems and range from oceans, freshwaters, soils and extreme habitats (for review see WhitTon \& PotTs 2000; WARREN-Rhodes et al. 2006). They are also important members of symbiotic relationships with lichens, plants, and other phototrophs (e.g., RAI et al. 2002; UsHer et al. 2007; ViLLANUEVA et al. 2019). Not merely relegated to aquatic habitats, cyanobacteria are also common terrestrial pioneers and form the basis of cryptogamic crusts (JOHANSEN 1993; BüDEL et al. 2002;
NGUYEN et al. 2017). Cyanobacteria are also important global ecosystem level engineers and their total biomass is estimated at ca. $3.0 \times 10^{14} \mathrm{~g} \mathrm{C}$ (GARCIA-PICHEL et al. 2003), and may constitute up to $50 \%$ of oceanic primary productivity (FALKOWSKI 2012). Although diatoms have been generally considered the standard algal bioindicators, routine cyanobacterial monitoring, especially in freshwater habitats, is increasing (MATEO et al. 2015; MonTEguARdo 2016). Non-toxic cyanobacteria are sources of food for many organisms, forming the base of the food web in aquatic ecosystems (Nweze 2009). Moreover, Nostoc and Arthrospira have been considered delicacies for centuries (Mexico, Peru, Lake Chad region of Africa and China; reviewed by Nweze 2009).

Cyanobacteria have other significant ecological roles, including global oxygen production (KASTING \& SiefERT 2002; Lyons et al. 2014) and carbon flux (CHARPY et al. 2012). In nitrogen-limited tropical ecosystems, they may be the primary source of nitrogen fixation (HofFMANN 1999; Abed et al. 2006; ChARPy et al. 2010). Marine cyanobacteria are responsible for ca. $50 \%$ of the global biological nitrogen fixation (GRUBER et al. 2008). While the filamentous, planktonic genus Trichodesmium represents a major marine nitrogen source (HOFFMANN 
1999; BergMAN 2001; CAPONE et al. 2005), small, unicellular, diazotrophic cyanobacteria (e.g., Crocosphaera watsonii, Synechococcus, Synechocystis) are also significant nitrogen contributors (SPILLER \& SHANMUGAM 1987; ZEHr et al. 2007; MoISANDER et al. 2010; SAHA et al. 2012), albeit with less efficiency (PAERL 2017). Although benthic cyanobacterial diversity in tropical coastal areas remains largely unexplored, their contribution to nitrogen fixation has already been documented (ABED et al. 2006; DíEz et al. 2007). It has been suggested that nitrogen limitation in tropical habitats has facilitated numerous symbiotic associations with both terrestrial and marine organisms (e.g., Geosiphon, Blasia, Azolla, Macrozamia, Gunnera, corals, sponges; reviewed by MeEKs 1998; LI 2009; LESSER et al. 2004).

In recent years, cyanobacteria have increasingly been studied for their roles in freshwater harmful algal blooms (for review see HuISMAN et al. 2005; PAERL \& Huisman 2009; QuibliER et al. 2013) and because their distribution and abundance are expected to increase with climate change (DvořÁK \& HAŠLER 2007; PEARL \& PAUL 2012; WILK-WoZNIAK et al. 2016), particularly global warming (ANTUNEs et al. 2015). For example, experiments have shown that increasing temperatures lead to a shift from the dominant native species Aphanizomenon gracile to the invasive species Raphidiopsis (previously Cylindrospermopsis) raciborskii (MEHNERT et al. 2010). However, these successional relationships are complex; for example, the coexistence of $R$. raciborskii and Planktothrix agardhii seems to be influenced by light intensity rather than by temperature, with the growth of shade adapted species $P$. agardhii favored by the co-occurrence of $R$. raciborskii due to its shading effect (HaŠLER \& PoulíčKová 2003; PoulíčKová et al. 2004; Bonilla et al. 2016).

Studies on tropical toxic cyanobacterial blooms are sporadic and the occurrence of toxic cyanobacterial strains is likely underestimated (reviewed by ANTUNES et al. 2015). The frequently occurring, planktonic genera Microcystis (occurring in tropical Asia, Africa and Central America), Raphidiopsis, and Anabaenal Dolichospermum (tropical Australia, America, Africa) have been recorded in tropical environments by Mowe et al. (2015). Tropical cyanobacteria are also being identified as potential competitors or pathogens of marine organisms, such as corals (e.g., black-band disease; STANIC et al. 2010; CASAMATTA et al. 2012). Toxins produced by cyanobacteria are even being recovered from aerial samples (WILDE et al. 2014; BREINLINGER et al. 2021). Numerous secondary metabolites have been identified from freshwater and marine taxa (e.g. BLÁHA et al. 2009; MAZARD et al. 2016). These metabolites include potent toxic compounds (DitTMAnN et al. 2013; MoreIRA et al. 2013), but also include a wide array of biologically active compounds that may be of human benefit, exhibiting anti-cancer, anti-viral, anti-bacterial, and anti-protistan properties (for review see SINGH et al. 2011; ZANCHETT \& Oliveira-Filho 2013).
Cyanobacteria were traditionally, broadly organized into four major lineages based on type of cell division and the presence of specialized cells. However, this system needs revision and no currently proposed taxonomic schemes are universally accepted (e.g., KomáreK 2010, 2011, 2018; KomÁreK et al. 2014). Taxonomic classification is confounded by the fact that cyanobacteria fall under both the International Code of Nomenclature of algae, fungi and plants and International Code of Nomenclature of Bacteria (Oren 2011; Oren \& Ventura 2017). While the most commonly employed scheme was introduced by RiPPKa et al. (1979) and modified by CASTENHOLZ et al. (2001), we, and most researchers now, employ the botanical approach and scheme set forth by KOMÁREK et al. (2014).

Traditionally, cyanobacteria have been extensively studied in temperate zones due to the prevalence of researchers associated with these habitats. Since 1994, an increasing attention has been paid to tropical cyanobacteria and their diversity (Fig. 1). However, the number of all species (Fig. 2) and newly described genera (Table 1) reflect unequal effort in respect to different tropical countries. Recent evidence suggests that the cyanobacteria as a whole possess much greater molecular diversity than is evidenced in morphology (e.g. Casamatta et al. 2003; HAŠLER et al. 2011, 2012, 2014a,b; SiLI et al. 2011; VACCARINO \& JOHANSEN 2011; PAlinSKa et al. 2012; DVOŘÁK et al. 2012, 2014, 2015b; HAUER et al. 2013; KomÁREK et al. 2013a,b; KomÁRKová et al. 2013; KRIENITZ et al. 2013; ENGENE et al. 2018). Questions still remain as to whether true tropical taxa even exist, or if cyanobacteria are ecologically ubiquitous in permissive habitats. Explanation will need more sequence data in public databases and higher accuracy in their identification, because many sequences refer only to cyanobacterial genera, or left unresolved as "uncultured" (Dvoř́́K et al. 2018). The purpose of this paper is to explore the state of tropical cyanobacterial diversity, ecological roles and putative evolutionary patterns. For the purposes of this paper, we define tropics as a region between subtropical high-pressure regions between 30-35 North and South latitudes (HENRY 2005).

\section{Cyanobacterial species concepts and definitions}

Inherent to any discussion of biodiversity are two main questions: i) what is a species and ii) how does cryptic diversity influence our notions about diversity? While cyanobacteria are technically bacteria, they have traditionally been regarded as "algae", and are governed by both the Botanical and Bacteriological Codes of Nomenclature. Although discussions of species concepts are not new (CASTENHOlZ \& Norris 2005; Oren \& GARRITY 2014; PALINSKA \& SuRosz 2014), cyanobacteria represent an especially problematic lineage. KOMÁREK (2010, 2011, 2018, 2020) published critical comments on some problematic aspects of cyanobacterial species designations. The author pointed out the necessity to 
study both natural populations and cultivated material in order to accurately account for phenotypic plasticity (for a review of potential issues arising from such plasticity see discussions by DrouET 1968, 1973). While traditionally organized based on major morphological features (e.g., presence or absence of specialized cells, types of cell division, mechanisms of reproduction, etc.), the currently accepted metric for species delineations is analysis of 16S rRNA gene (e.g. NüBEL et al. 2008; ITEMAN et al. 2000) similar to bacteria (CARO-QUINTERO \& KonSTANTINIDIS 2012). Unfortunately, the 16S rRNA gene itself does not provide sufficient resolution for species level designations in cyanobacteria (JOHANSEN \& CASAMATtA 2005; CASAMATTA et al. 2005), and thus may miss critical cryptic diversity (CASAMATTA et al. 2003). Moreover, multiple ribosomal operons are often present in the cyanobacterial genomes. While they are almost identical in most cases, Scytonema hyalinum possesses two types of highly diverged operons with 7.3-9.0\% of difference between them (JOHANSEN et al. 2017).

Researchers are increasingly also employing 16S-23S ITS secondary folding structures as phylogenetically informative characters, as this region easily undergoes changes more than the conservative 16S rRNA gene. In addition, resolution on the species or infraspecific level is very high (LuKEŠOví et al. 2009; PERKERSON et al. 2011; OsORIO-SANTOS et al. 2014) and so the ITS secondary structures represent another effective tool of modern taxonomy of cyanobacteria (e.g. BOYER et al. 2001; CASAmatta et al. 2006; Siegesmund et al. 2008). To avoid the problems associated with single-gene phylogenies, multilocus and phylogenomics datasets are also being utilized (AHLGREN et al. 2012; MAZARD et al. 2012; KoMÁREK et al. 2014; SCHIRRMEISTER et al. 2015; Alvarenga et al. 2017; Mareš 2018). Another method with a sufficient resolution to recognize cryptic lineages is peptide/protein profiles (intact cell MALDITOF - matrix assisted laser desorption ionization-time of flight mass spectrometric analysis). While this method seems to have higher sensitivity than analysis of $16 \mathrm{~S}$ rRNA gene, while being both cheaper and simpler then genomic analysis (ŠEBELA et al. 2018), few researchers employ this method at present.

Current classification of cyanobacteria employs a polyphasic approach, using study of natural populations and cultures, a detailed evaluation of morphological variability, ecology of species, ultrastructure and molecular analysis (KOMÁREK 2018, 2020). Current estimates indicate that there exist $>6000$ species of cyanobacteria (NABOUT et al. 2013), but this estimate is highly conservative and probably will be shattered as more habitats are sampled. Further, with an advent of next generation sequencing, it has become obvious that the ITS patterns can only provide limited insights into diversity. Phylogenomic analyses (phylogenies based on a whole genome data) reveal that there appear cryptic species (taxa, ecotypes),
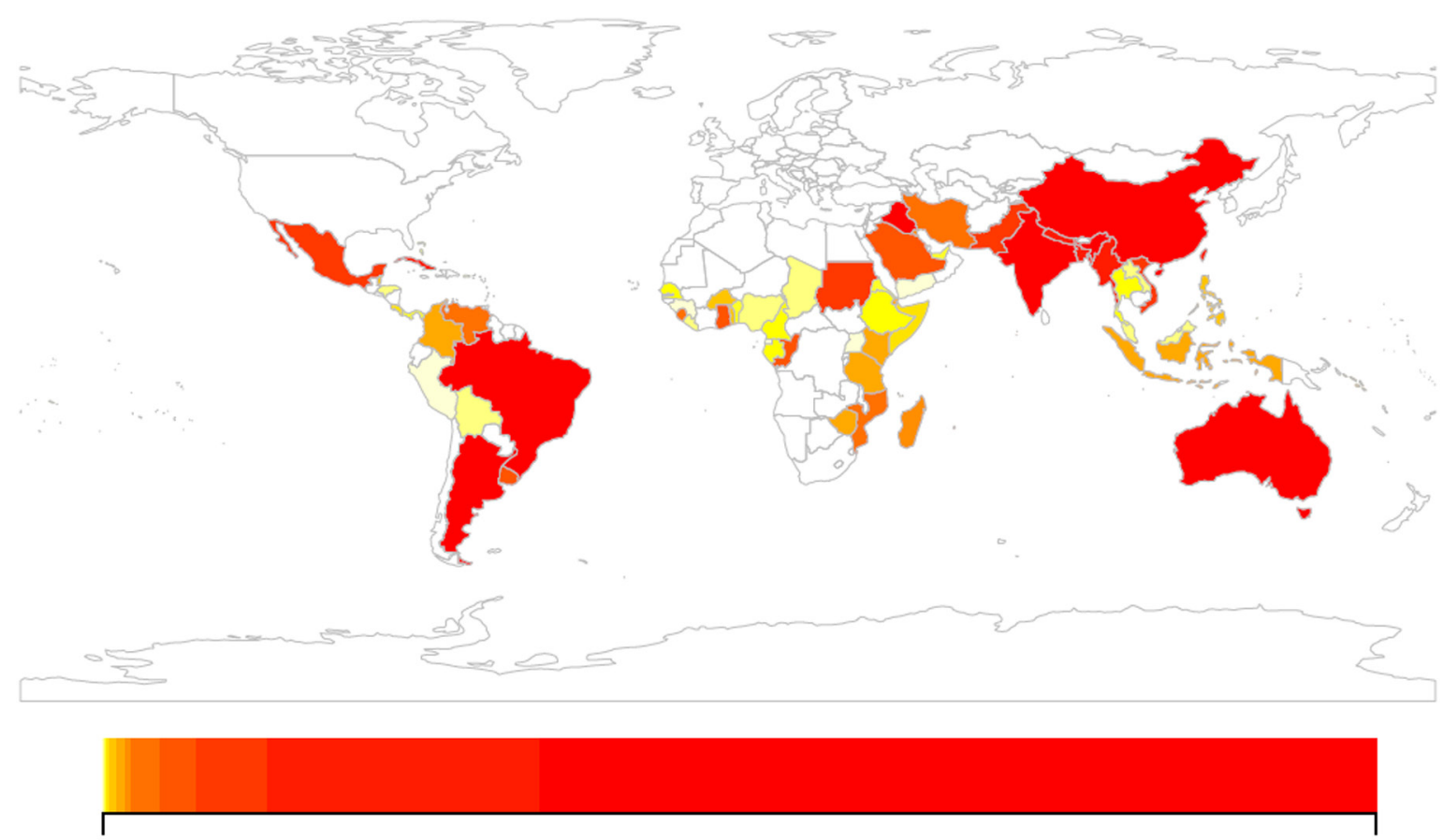

1

No. of species found in a country

Fig. 1. Cyanobacterial diversity in the tropical countries. The color gradient represents the number of species found per country. All accession numbers from tropical countries were downloaded for the whole world from AlgaeBase (12 February 2020, https://www.algaebase.org/search/ distribution/). The number of species found in a particular country was drawn using R (R Core Team 2020), package rworldmap 1.3-6 (https:// cran.r-project.org/web/packages/rworldmap/index.html). 
which might be identified only using whole genome data (e.g. RocAP et al. 2003). While 411,496 complete or draft genomes are available for bacteria, only 1,842 cyanobacterial draft or complete genomes are available in NCBI (22nd February 2021). Thus, cyanobacteria are still behind with data in comparison to other prokaryotes (Alvarenga et al. 2017). DvořáK et al. (2020) showed that whole-genome of cyanobacterial herbarium specimens can be sequenced. Herbarium specimens may provide a unique source of reference data for the phylogenomic analyses and taxonomic revisions.

Recent research suggests that tropical cyanobacterial biodiversity is likely extremely high. The actual elucidation of this diversity is confounded by morphological similarity with species from temperate zones and cryptic diversity, which requires the use of sensitive phylogenetic methods. Further, a dearth of specialized modern keys from the tropics leads to more difficulties. The most comprehensive key books on tropical cyanobacteria were published by GARDNER (1927), FRÉMY (1930) and DESIKACHARY (1959). The three recently published monographs of the Süsswasserflora von Mitteleuropa keys (KoMÁREK \& ANAGNOSTIDIs 1999, 2005; KOMÁREK 2013) are the most employed cyanobacterial keys throughout the world. Unfortunately, these books focus almost exclusively on European flora, while taxa occurring in the tropical regions are mentioned without keys to their identification. The expected occurrence of cosmopolitan species and number of tropical species in the aforementioned recent and classical monographs enable their common use as the basic source of knowledge for studying diversity of tropical cyanobacteria.

Another caveat in an identification of the tropical cyanobacteria lies in the frequent polyphyly within almost all cyanobacterial genera. For example, cosmopolitan genera such as Phormidium, Leptolyngbya, Microcoleus, and Synechococcus are composed of several lineages without common origin but with a coherent morphology. The most recent and complex review is given in KomÁREK et al. (2014), who proposed to call these polyphyletic conglomerates "cryptogenera". In some cases, such morphological coherence may mask a geographical origin. For example, Pseudanabaena galeata frequently occurs in the plankton of fresh-water lakes in the temperate zone. Recently, a morphologically indistinguishable morphospecies has been isolated from the plankton of tropical fresh-water bodies. However, phylogenetic analyses of $16 \mathrm{~S}$ rRNA regions has revealed the tropical morphospecies actually belong to another lineage distantly related to $P$. galeata, Pinocchia polymorpha (Dvoř́́K et al. 2015a). In many cases, genetic differences are quite extensive. For example, two newly identified genera Ammassolinea (HAŠLER et al. 2014b) and Jacksonvillea (HAŠLER et al. 2017) found in Florida showed that they were $\sim 10 \%$ different from other cyanobacteria $16 \mathrm{~S}$ rRNA sequences stored at GenBank. A survey of the GenBank 16S rRNA sequences by DvořÁK et al. (2018) revealed that only $21 \%$ of species stored there are correctly identified, further emphasizing potential problems arising from the cryptogenera.

Although the trend to erect new taxa is robust (see Table 1), most of the studies are based on one or two strains, perhaps leading to spurious results as additional strains are sequenced. To articulate this issue, PIETRASIAK et al. (2019) studied Myxacorys gen. nov. from desert soil crusts. They isolated 42 strains and proposed a new genus with two new species Myxacorys californica and $M$. chilensis on the basis of $16 \mathrm{~S}$ rRNA

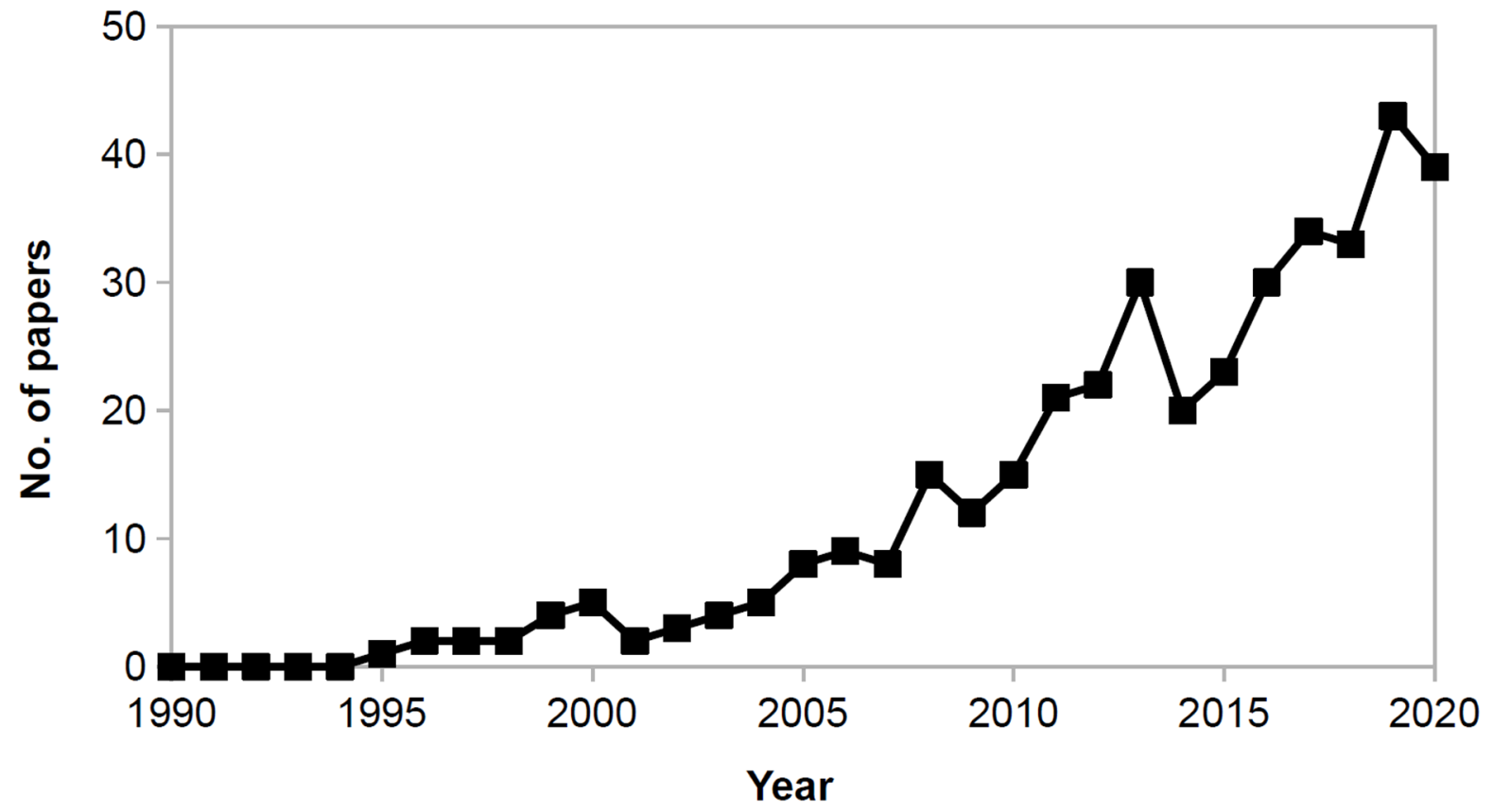

Fig. 2. Number of papers from Web of Science (to date 22 February 2021) which dealt with the tropical diversity of cyanobacteria each year employing the terms: cyanobacteria, diversity, tropics, and a particular year. 
gene sequences. But they also found distinct 16S-23S ITS sequence variability within species, with three distinct lineages within $M$. californica and five within $M$. chilensis. They articulated this surprising result with the question: "what is the line between species, or, put differently, when is it justified to describe a cyanobacterial species?" (PIETRASIAK et al. 2019).

\section{Pioneer morphological studies}

Little attention has been paid to tropical cyanobacteria and their diversity. The most important and comprehensive first monographs on tropical cyanobacteria were published by FrÉMY (1930) and DESIKACHARY (1959), who studied diversity across Paleotropical regions. Both authors classified cyanobacteria employing a traditional botanical approach. Frémy reported 227 species of cyanobacteria from equatorial Africa, representing 57.9\% of the total cyanobacterial diversity in Africa (392 species). The author distinguished three groups of species: i) cosmopolitan or species occurring across the world, ii) exclusively tropical species, and iii) those taxa which occurred only in equatorial Africa (most likely endemic species). Frémy collected cyanobacterial samples from diverse habitats, including dry rocks, wet soils and wet bark, leaves, and mosses. Aquatic habitats elicited a higher diversity of cyanobacteria. Numerous taxa were found as periphyton on submerged trees, plants, stones, etc. or free-floating, including many traditional temperate genera.

DESIKACHARY (1959) reported 85 genera and 750 species of cyanobacteria in India and surroundings regions. Approximately 145 species were designated as cosmopolitan and $31 \%$ of species corresponded to European records. A similar situation described KOMÁREK (1985) who recorded $45 \%$ rate of endemism from Cuba. Gardner (1927) described 216 new species of neotropical flora in the monograph New Myxophyceae from Puerto Rico, among which Lyngbyopsis willei (a monotypic genus) represents an endemic cyanobacterium of the Caribbean region. Floristic research from the other countries in Central America (Mexico, Belize) showed a high diversity of cyanobacteria and numerous new species or genera were found in various habitats. Historical records indicate that tropical habitats contain both autochthonous tropical flora as well as cosmopolitan species. Tropical cyanobacteria can be pantropical or restricted to narrow, geographically limited regions.

GARDNER (1927) described many genera commonly encountered in temperate regions, but with high intrageneric diversity. For example, Scytonema included 22 species and varieties, of which the majority represents species found only in Puerto Rico. However, it must be noted that recent molecular analyses have erected new genera to encompass many of these taxa, such as Chakia (Komárkoví et al. 2013; formerly Sc. catenulum, Sc. evanescens) or Brasilonema (Sc. lyngbyoides). Similarly, the genus Stigonema showed a high intrageneric diversity (15 species and varieties), the majority of which have only been found in Puerto Rico (St. hormoides var. constrictum, var. rigidum, var. lineare), potentially representing new taxa.

\section{Modern polyphasic studies}

Recently, researchers have greatly expanded our knowledge of cyanobacterial diversity in tropical habitats (Table 1, Fig. 1, Fiore et al. 2007; SANT'AnNA et al. 2010, 2011; RAMÍREZ et al. 2011; SANT'ANNA et al. 2011; LEMESDA-SiLva et al. 2012; JAHODÁŘoví et al. 2017, 2018). The reasons for such increase can be found in general globalization - accessibility of traveling, increasing use of molecular methods, and expansion of polyphasic studies. The description of new genera in Table 1 has been achieved using a polyphasic approach supported by International Association for Cyanophyte Research (IAC) (KoMÁreK 2011).

First, it may be argued that the prevalence of tropical cyanobacteria may be increasing in both terms of abundance and distribution. For example, migratory birds to Europe or across America can introduce tropical species such as Raphidiopsis raciborskii, which may be successfully established due to global climate change (Dyble et al. 2002; Mehnert et al. 2010; SUKENIK et al. 2012). Cellamare et al. (2013) have pointed out that cyanobacterial dispersal along the Aquitaine region of France is due to birds migrating from Africa. In general, planktic species are expected to have wider, easier dispersion than benthic taxa (NASELLI-FLORES \& PADISÁK 2016).

Second, the pioneering works examining tropical cyanobacterial diversity were based solely on light microscopy (LM) studies. However, the limited resolution of LM, coupled with simple cyanobacterial morphology, subtle apomorphies, and potentially widespread cryptic diversity represent the limitations of taxonomy in the $19^{\text {th }}$ and $20^{\text {th }}$ centuries (CASAMATTA et al. 2003; SHERWOOD et al. 2015; ENGENE et al. 2018). The lack of keys to tropical taxa led to further confusion, with many temperate taxa described from tropical areas due to an overreliance on morphological assessments. For example, ENGENE et al. (2011, 2012, 2013a, 2013b, 2018) focused on the ubiquitous tropical marine genus "Lyngbya". Using molecular, morphological, and chemotaxonomic characters, they have clearly demonstrated vast phylogenetic diversity in what has traditionally been considered a species depauperate clade. In contrast, the genus Sphaerocavum, which co-occurs with Microcystis in eutrophic Brazilian lakes, was initially described as a separate genus based on morphology (AzEvEdo \& SANT'ANNA 2003), but later phylogenetic analyses revealed this to be mere phenotypic plasticity (RIGONATO et al. 2018).

One of the most-studied tropical areas is Central and Southern America. Specialists have begun to investigate freshwater, subaerophytic, and aerophytic populations of cyanobacteria from Cuba, Mexico, Belize and Brazil, which has resulted in numerous new taxa (Fig. 2, Table 1, e.g. KomáreK \& Hindák 1975; Montejano 
Table 1. New genera described from tropical environments (2015-2020). Data based on CyanoDB http://www.cyanodb.cz/.

\begin{tabular}{|c|c|c|c|c|}
\hline Genus & References & Habitat & Taxonomic lineage & Area \\
\hline Aliterella & RigONATO et al. 2016 & Marine & Chroococcidiopsidales & Brazil \\
\hline Aliinostoc & BAGCHI et al. 2017 & Benthic & Nostocales & India \\
\hline Alkalinema & VIEIRA VAZ et al. 2015 & Saline wetland & Synechococcales & Brazil \\
\hline Amazoninema & GENUÁRIO et al. 2020 & Stream & Synechococcales & Brazil \\
\hline Amphiheterocytum & SANT' ANNA et al. 2019 & Planktic & Nostocales & Brazil \\
\hline Ancylothrix & MARTINS et al. 2016 & Stream benthos & Oscillatoriales & Brazil \\
\hline Caldora & ENGENE et al. 2015 & Marine & Oscillatoriales & Florida \\
\hline Capilliphycus & CAIRES et al. 2019 & Marine & Oscillatoriales & Brazil \\
\hline Cephalothrix & MALONE et al. 2015 & Lake & Oscillatoriales & Brazil \\
\hline Crocosphaera & MAREš et al. 2019 & Marine & Chroococcales & Brazil \\
\hline Cryptococcum & GAMA et al. 2019 & Terrestrial & Chroococcales & Brazil \\
\hline Dapis & ENGENE et al. 2018 & Marine & Oscillatoriales & Florida \\
\hline Dapisostemon & HentschKe et al. 2016 & Epidendric & Nostocales & Brazil \\
\hline Desikacharya & SARAF et al. 2019a & Freshwater & Nostocales & India \\
\hline Dictyophoron & KOMÁREK et al. 2017 & Bentic & Nostocales & Belize \\
\hline Dulcicalothrix & SARAF et al. $2019 \mathrm{~b}$ & Oligotrophic lake & Nostocales & India \\
\hline Elainella & JAHODÁŘOvá et al. 2018 & Planktic & Synechococcales & Vietnam \\
\hline Euryhalinema & CHAKraborty et al. 2019 & Soil & Synechococcales & India \\
\hline Ewamiania & McGREGOR \& SENDALl 2017a & Thermal springs & Nostocales & Australia \\
\hline Foliisarcina & AlvARENGA et al. 2016 & Aerophytic & Pleurocapsales & Brazil \\
\hline Goleter & Miscoe et al. 2016 & Cave wall & Nostocales & Hawaii \\
\hline Gloeomargarita & MoREIRA et al.2017 & Lake biofilm & Gloeomargaritales & Mexico \\
\hline Halotia & GENUÁRIO et al. 2015 & Mangrove soil & Nostocales & Brazil \\
\hline Chamaethrix & DvořÁk et al. 2017 & Soil crust & Synechococcales & Florida \\
\hline Chroakolemma & BECERRA-AbSOLÓn et al. 2018 & Desert soil & Synechococcales & Mexico \\
\hline Inacoccus & GAmA et al. 2019 & Terrestrial & Chroococcales & Brazil \\
\hline Iningainema & Mc.GreGOR \& SENDALl 2017b & Spring & Nostocales & Australia \\
\hline Jacksonvillea & HAŠLER et al. 2017 & Bentic & Oscillatoriales & Florida \\
\hline Komarekiella & HentschKe et al. 2017 & Aerophytic & Nostocales & Brazil \\
\hline Komarkovaea & MAI et al. 2018 & Waterfalls & Synechococcales & Puerto Rico \\
\hline Kovacikia & Miscoe \& JohanSEn 2016 & Cave wall & Synechococcales & Hawaii \\
\hline Kryptousia & Alvarenda et al. 2017 & Aerophytic & Nostocales & Brazil \\
\hline Lagosinema & AKAGHA et al. 2019 & Brackish & Synechococcales & Nigeria \\
\hline Leptoelongatus & Chakroborty et al. 2019 & Soil & Synechococcales & India \\
\hline Macrochaete & BERRENDERO et al. 2016 & Soil crust & Nostocales & Brazil, Spain \\
\hline Marileptolyngbya & ZHou et al. 2018 & Marine & Synechococcales & China \\
\hline Minunostoc & CAI et al. 2019 & Epilithic & Nostocales & China \\
\hline Myxacorys & Pietrasiak et al. 2019 & Soil crust & Synechococcales & Chile \\
\hline Neolyngbya & CAIRES et al. 2017/18 & Bentic marine & Oscillatoriales & Brazil \\
\hline Neowollea & TAwONG et al. 2019 & Freshwater & Nostocales & Thailand \\
\hline Nunduva & GONZÁLEZ-RESENDIZ et al. 2018 & Marine & Nostocales & Mexico \\
\hline Onodrimia & JAHODÁŘOVÁ et al. 2017 & Epixylon & Synechococcales & $\begin{array}{l}\text { Java, Indo- } \\
\text { nesia }\end{array}$ \\
\hline Pantanalinema & VIEIRA VAZ et al. 2015 & Saline wetland & Synechococcales & Brazil \\
\hline Pelatocladus & Miscoe et al. 2016 & Cave wall & Nostocales & Hawaii \\
\hline Perforafilum & Zimba et al. 2020 & Hypersaline & Oscillatoriales & Texas \\
\hline
\end{tabular}




\begin{tabular}{|c|c|c|c|c|}
\hline \multicolumn{5}{|l|}{ Table 1 Cont. } \\
\hline Phyllonema & ALVARENGA et al. 2016 & Aerophytic & Nostocales & $\begin{array}{l}\text { Brazil, Me- } \\
\text { xico }\end{array}$ \\
\hline Potamolinea & MARTINS \& BRANCO 2016 & Stream & Oscillatoriales & Brazil \\
\hline Potamosiphon & McGReGOR \& SENDALl 2019 & Epilithic & Oscillatoriales & NE Australia \\
\hline Purpureonostoc & CAI et al. 2020a & Soil & Nostocales & Tibet, China \\
\hline Pycnacronema & MARTINS et al. 2018 & Aerophytic & Oscillatoriales & Brazil \\
\hline Reptodigitus & Casamatta et al. 2020 & Epizoic & Nostocales & Florida \\
\hline Rippkaea & MAREŠ et al. 2019 & Terrestrial & Chroococcales & Taiwan \\
\hline Salileptolyngbya & Zhou et al. 2018 & Marine & Synechococcales & China \\
\hline Sinocapsa & WANG et al. 2019 & Aerophytic & Ordo incertae sedis & China \\
\hline Sodaleptolyngbya & Cellamare et al. 2018 & Stromatolites & Synechococcales & $\begin{array}{l}\text { Mayotte } \\
\text { Island }\end{array}$ \\
\hline Sodalinema & Cellamare et al. 2018 & Planktic & Synechococcales & Mayotte island \\
\hline Stenomitos & MiscoE et al. 2016 & Cave wall & Synechococcales & Hawaii \\
\hline Toxifilum & ZIMBA et al. 2017 & Bentic & Synechococcales & Texas \\
\hline Violetonostoc & CAI et al. 2020b & Epilithic & Nostocales & China \\
\hline Zehria & MAREŠ et al. 2019 & Marine & Chroococcales & Florida \\
\hline
\end{tabular}

et al. 1993, 1997; GolD-Morgan et al. 1994; KoMÁREK \& KomÁrKová-LEgnerová 2002, 2007; SANT'AnNA et al. 2010; FIORE et al. 2007).

Compared to temperate regions, the tropics span a larger continuous geographic area. Coupled with relatively low seasonality and high humidity, this may enable many species to coexistence (MitTELBACH et al. 2007). For example, subaerial microalgae have higher diversity in tropical/subtropical, subaerial habitats compared to temperate ecosystems (ELDRIDGE 2001; ORTEGA-MORALES et al. 2006; NEUSTUPA \& ŠKALOUD 2008; KESHARI \& ADHIKARY 2014; SHERWOOD et al. 2015; NGUYEN et al. 2017). Moreover, cyanobacteria were found to be the second most abundant group of algae in these habitats, particularly in open spaces with higher light intensities (NeustuPA \& ŠKaloud 2008). Cyanobacteria possess several advantages (e.g., sheath production, accessory pigments, baeocytes, etc.) that may allow them to thrive in these high light habitats (VILLANUEVA et al. 2019a,b).

\section{Cyanobacterial adaptability}

Cyanobacteria are unique by the wide range of adaptations to environmental conditions. Tropical zones include habitats from deserts to rainforests covering gradients of temperature, light, water and nutrient availability. Sheath/mucilage production in cyanobacteria represent an adaptation to water content fluctuation and is especially important in developing the structure of soil biological crusts (Belnap et al. 2001; PietrasiaK et al. 2019). Sheaths contain UV protective molecules like scytonemin or gloeocapsin (FLEMING \& CASTENHOLZ 2007), and this mucilage is responsible for the gliding motility of cyanobacteria (HoITZYK 2000). Cyanobacteria excel at elevated temperatures (SINETOVA et al. 2017;
Pedersen \& Miller 2017). N-fixation capacities of cyanobacteria comprise an advantage in nutrient limited tropical environments (CHARPY et al. 2010; MAREŠ et al. 2019). Lastly, the unrivalled capacity for extensive chromatic adaptation allows tolerance of both low and high light conditions. Phycobilins allow photon capture between the blue and red regions of the spectrum that are not efficiently trapped by chlorophyll (KEHOE 2010). If the environment proves too inhospitable, cyanobacteria can also produce resting cells (akinetes).

\section{Endemic vs. cosmopolitan taxa}

There is currently much debate pertaining to the notion of endemic vs. cosmopolitan microbes in general (e.g., FINLAY 2002; DvořÁK et al. 2012). Echoing this debate, cyanobacterial researchers are increasingly willing to erect new genera based on putatively endemic organisms (e.g., Flechtner et al. 2002; Casamatta et al. 2006). For example, the genus Brasilonema, originally described from Brazil (FIORE et al. 2007), has been found to have wider distribution (BECERRA-ABSALON et al. 2013; VACCARINO \& JOHANSEN 2012; VILLANUEVA et al. 2019a; BARBosa et al. 2021). Moreover, studies show that the distribution pattern may rather be taxa specific and any general pattern cannot be drawn among the cyanobacteria.

Conversely, the ubiquitous cyanobacteria Synechococcus and Prochlorococcus have traditionally been considered global and cosmopolitan in marine habitats, yet recent evidence has challenged this notion. Molecular evidence points to several distinct genetic lineages of both genera, indicating more habitat preferences than previously assumed (ZwIRGLMAIER et al. 2007, 2008; AHLGREN \& RocAP 2012; MAZARD et al. 2012). DvořÁK et al. (2012) point out that the cosmopolitan mat-forming 
Microcoleus vaginatus exhibits episodic genetic isolation which mimics a perceived biogeographic pattern.

Even when a taxon evolves in a tropical habitat, it may expand its range as the environment changes. For example, the common planktonic cyanobacterium, Raphidiopsis raciborskii, was initially considered a strict tropical taxon. Yet as climate changes and temperatures increase, it has been considered to be a microbial invader throughout North America (GUGGER et al. 2005; KLING 2009) and the temperate zone (AGUILERA et al. 2018). This increased geographical range may be the result of environment changes (BRIAND et al. 2004; DvOřÁK \& HAŠLER 2007; BONILA et al. 2016), a result of allelopathic potential (BRANCO \& SENNA 1994; ANTUNES et al. 2015), or innate ecophysiological tolerances (PADISÁK 1997; ANTUNES et al. 2015). The great degree of genetic divergence within this lineage (MOREIRA et al. 2011; WooD et al. 2014) also revealed that radiation within continents is more probable than the recent exchange between continents (HAANDE et al. 2008; RiBEIRO et al. 2020). Thus still, it is not certain whether the expansion of Raphidiopsis raciborskii from tropical habitats is a result of enormous ecophysiological range or existence of ecologically differentiated ecotypes (ANTUNES et al. 2015). Likewise, the putatively tropical genus Komarekiella was described from Brazil and Hawaii (HentschKe et al. 2017), but was morphologically indistinguishable to Chlorogloeopsis, with vast cultural phenotypic plasticity. However, this genus has subsequently been recovered from additional habitats in Florida, so the distribution may be more limited by researcher's ability to culture and identify it, rather than eco-physiological constraints (Brown et al. 2021).

Patterns of distribution may be difficult to articulate, as evidenced by the common, cosmopolitan, taxon Microcystis aeruginosa. Van GREMBERGHE et al. (2011) and RIBEIRo et al. (2020) did not find any morphological or genetic diversity in Microcystis aeruginosa using single gene analyses. However, studies based on a concatenated set of four loci revealed some genetic diversity in this species (MoreIRA et al. 2014). They proposed an early origin of $M$. aeruginosa in the African continent, with subsequent European populations having a cosmopolitan distribution. However, CAPELLI et al. (2017) found significant genetic differences (including differences in capability to synthesize microcystins) among another global, cosmopolitan taxon, Dolichospermum lemmermannii, isolates.

Some level of endemism maybe expected in "island environments", such as hot geothermal springs (PAPKe et al. 2003, WhitaKer et al. 2003). Indeed, the occurrence of both endemic and cosmopolitan species (with respect to temperature) from other thermal environments has been witnessed in Zerka Ma' in hot springs (IONESCU et al. 2010). The "island effect" may also be common in other unusual habitats, such as hypogean, subterranean, and cave systems. For example, while Albertania skiophila has been described as endemic to
Maltese hypogea (ZAMmit 2018), the biodiversity of these environments is poorly known, and thus additional research of caves and catacombs is necessary (LAMPRIOU et al. 2013; MiscoE et al. 2016).

\section{Undersampling of tropical cyanobacteria}

One possible reason for the lack of perceived tropical diversity could be attributed to sampling efforts (sensu FinLAY 2002). The vast majority of described cyanobacterial taxa have been from temperate regions; not coincidentally, this is where the majority of cyanobacterial researchers reside. To illustrate this bias, we present a map of a number of identified cyanobacteria in the tropical countries (Fig. 1). We found that only Cuba, Mexico, Brazil and Argentina have high number of identified species in South and Central America. As a whole, the African continent seems to be less studied. Most of the countries have unknown diversity, with the most studied being Ethiopia, Ghana, Republic of the Congo, and Sierra Leone. The best studied regions in Asia were India, Nepal, Myanmar, Bangladesh, China, and Vietnam. Australia has well-studied cyanobacterial diversity as well, likely due to the presence of researchers and concerns about eutrophication.

However, recent works by researchers from tropical habitats have begun to greatly expand our knowledge of diversity (see references elsewhere). In a review of Web of Science papers from February 22, 2021, we note that 5771 papers pertain to the "diversity of cyanobacteria", while a mere 394 deal with "tropical diversity of cyanobacteria", most of which are limited floristic studies based solely on morphological examination of samples (see problems with cryptic diversity above). There were no such papers indexed at Web of Science dealing with a tropical diversity of cyanobacteria until 1994. Since 1995, however, interest has rapidly increased, nearing 40 papers per year in 2020 (Fig. 2).

Another potential reason for the dearth in tropical sampling is that not all cyanobacteria are equally "important" to human endeavors. For example, Microcystis aeruginosa is very commonly encountered as a toxic taxon and thus is often sequenced. Further, planktonic taxa are commonly sequenced due to their prevalence, ubiquity, and visibility to researchers (PoulíčKoví et al. 2014). Conversely, many other cyanobacterial taxa may not be sequenced enough (for example, those from unusual habitats or those not typically considered "nuisance" taxa). In the end, it may be that questions pertaining to tropical diversity are intimately related to the phylogenetic markers employed (see above). Thus, it appears that the question of tropical cyanobacterial endemism and biogeographical patterns in general depends on the level of resolution and markers employed.

\section{Driving factors of microbial diversity}

Latitudinal gradients are considered primary factors in the distribution and diversity of plants and animals (for a review see MittelbaCH et al. 2007). Species diversity 
increases as one travels closer to the equator (HILLEBRANDT 2004), although some lineages exhibit inverse latitudinal gradients (KINDLMANN et al. 2007). Using fossil records, MANNION et al. (2014) noted that peaks in tropical species diversity seem to be restricted to intervals of the Palaeozoic and the past 30 million years. BROMHAM \& CARDillo (2003) suggest that rates of mutagenesis and evolutionary divergence increase closer to the equator; although this work was from macroscopic eukaryotes, and the application to microbes remains unknown. Conversely, PASSY (2010) has reported an exception to this general pattern in her study of continental lotic water diatoms from the U.S., which exhibit a U-shaped latitudinal distribution of richness. WRIGHT et al. (2006) calculated a doubling rate of nucleotide substitutions in the tropics, but no one has calculated such a rate using cyanobacteria. Evolutionary scenarios might explain this phenomenon. First, diverse resources may support more specialized organisms, which in turn may foster greater amounts of productivity (BROMHAM \& CARDILLO 2003). Second, biological processes (e.g. reproduction, speciation) are faster in elevated temperatures because of faster kinetics of biological processes (Evans et al. 2005; GiLlOoLY et al. 2005).

The factors that influence bacterial latitudinal diversity are subject to intensive debate in the literature. For example, in a review and meta-analysis of 111 studies by LOZUPONE \& KNIGHT (2007), they conclude that it is salinity, and not extremes of temperature, $\mathrm{pH}$, or other physical and chemical parameters, that is the most important parameter structuring bacterial communities. Conversely, in a review by HoRNER-DEvine et al. (2004), the authors note that bacterial biodiversity follows the same patterns observed in plants and animals. When examining marine bacterioplankton, FUHRMAN et al. (2008) showed that latitudinal patterns are similar in plants and animals, with temperature being a driving factor. Marine bacterioplankton exhibit significantly increased numbers of detected genotypes towards the equator. A meta-analysis of 3502 sampling experiments performed by TAMAMES et al. (2010) revealed salinity, temperature, and animal tissue type as the most important selective environmental characteristics. SoININEN (2012) echoed this latitudinal pattern in a review of macroecology of unicellular organisms. STOMP et al. (2011) posited that strong latitudinal, longitudinal and altitudinal gradients all impact the diversity and distribution of phytoplankton from 540 lakes across North America. Thus, it appears that the factors most important for distribution and biodiversity of microbes in general, and cyanobacteria in particular, appear to be difficult to untangle and perhaps subject to myriad forces not always evident to researchers.

\section{Trends and perspectives}

Several potential future endeavors will greatly expand our knowledge of tropical cyanobacterial diversity. First, more extensive, comprehensive floristic surveys in these habitats need undertaking. Identification keys from tropical regions should be expanded and updated. Further, attention to seldom sampled geographic regions, countries, and habitats (e.g., subaerial, benthic, endolithic) needs to be increased (NEUSTUPA \& ŠKALOUD 2008; PoulíčKovÁ et al. 2014). Second, more attention to molecular markers for taxonomic identification is of great importance. This will help ameliorate issues arising from cryptic diversity. However, it must be noted that sequences from GenBank may be misidentified or inaccurate, so a better method of validating sequences and taxonomic assignments will be warranted. Third, hypotheses relating to elevated rates of evolution (i.e., via increased substitution rates) can be explored and tested by researchers. Fourth, biogeographic patterns can be elucidated by more nuanced approaches (e.g., genomic analyses, molecular markers), rather than relying merely upon morphological examinations.

\section{ACKNOWLedgements}

This work was supported by project ESF CZ.1.07/2.3.00/30.0041, Grant Agency of the Czech Republic No. 19-12994Y, and the Internal Grant Agency of the Palacký University Prf-2021-001.

Author contributions

P. Dvořák: original concept, drafting; P. Hašler: taxonomy, editing; A. Poulíčková: literature search, manuscript editing, formatting; D. Casamatta: drafting, editing, English and style unification

\section{REFERENCES}

Abed, R.M.M.; Palinska, K.A.; Camoin, G. \& Golubic, S. (2006): Common evolutionary origin of planktonic and benthic nitrogen fixing oscillatoriacean cyanobacteria from tropical oceans. - FEMS Microbiology Letters 260: 171-177.

Aguilera, A.; Gómez, E.B.; KašTovsKÝ, J.; ECheniQue R.O. \& SALERNO G.L. (2018): The polyphasic analysis of two native Raphidiopsis isolates supports the unification of the genera Raphidiopsis and Cylindrospermopsis (Nostocales, Cyanobacteria). -Phycologia 57: 130-146.

Ahlgren, N.A. \& RocAP, G. (2012): Diversity and distribution of marine Synechococcus: multiple gene phylogenies for consensus classification and development of qPCR assays for sensitive measurement of clades in the ocean. - Frontiers in Microbiology 3: 213.

Akagha, S.C.; Johansen, J.R.; Nwankwo, D.I. \& Yin, K. (2019): Lagosinema tenuis gen. et sp. nov. (Prochlorotrichaceae, Cyanobacteria): a new brackish water genus from Tropical Africa. - Fottea 19: 1-12.

Alvarenga, D.O.; ANdreote, A.P.D.; Branco, L.H.Z. \& Fiori, M.F. (2017): Kryptousia macronema gen. nov., sp. nov. and Kryptousia microlepis sp. nov., nostocalean cyanobacteria isolated from phyllospheres. - International Journal of Systematic and Evolutionary Microbiology 67: 3301-3309.

Alvarenga, D.O.; Fiore, M.F. \& Varani, A.M. (2017): A metagenomics approach to cyanobacterial genomics. - Frontiers in Microbiology 8:e809.

Alvarenga, D.O.; Rigonato, J.; Branco, L.H.Z.; Melo, I.S. \& Fiore, M.F. (2016): Phyllonema aviceniicola gen. nov., sp. nov. and Foliisarcina bertiogensis gen. nov., sp. nov., epiphyllic cyanobacteria associated 
with Avicennia schaueriana leaves. - International Journal of Systematic and Evolutionary Microbiology 66: 689-700.

Antunes, J.T.; Leão, P.N. \& Vasconcelos, V.M. (2015): Cylindrospermopsis raciborskii: review of the distribution, phylogeography, and ecophysiology of a global invasive species. - Frontiers in Microbiology 6: 473

Azevedo, M.T.P. \& SAnT'AnNA, C.L. (2003): Sphaerocavum a new genus of planktic Cyanobacteria from continental water bodies in Brazil. -Algological Studies 79: 79-92.

Bagchi, S.N.; DubeY, N. \& Singh, P. (2017): Phylogenetically distant clade of Nostoc-like taxa with the description of Aliinostoc gen. nov. and Aliinostoc morphoplasticum sp. nov. -International Journal of Systematic and Evolutionary Microbiology 67: 3329-3338

Barbosa, M.; Berthold, D.E.; LefLer, F.W. \& LAUGhinghouse IV, H.D. (2021): Diversity of the genus Brasilonema (Nostocales, Cyanobacteria) in plant nurseries of central Florida (USA) with the description of three new species: $B$. floreae sp. nov., $B$. santannae sp. nov. and B. wernerae sp. nov. - Fottea 21: 82-99.

BeCerRa-Absalón, I.; Johansen, J.R.; MuÑoz-Martín, M.A. \& Montejano, G. (2018): Chroakolemma gen. nov. (Leptolyngbyaceae, Cyanobacteria) from soil biocrusts in the semi-desert Central Region of Mexico. - Phytotaxa 367: 201-218.

Becerra-Absalón, I.; Rodarte, B.; Osorio, K.; Alba-Lois, L.; Segal-Kischinevzky, D. \& Montejano, G. (2013): A new species of Brasilonema (Scytonemataceae, Cyanoprokaryota) from Tolantongo, Hidalgo, Central Mexico. - Fottea 13: 25-38.

Belnap, J.; Kaltenecker, J.H.; Rosentreter, R.; Williams, J.; LEONARD, S. \& ELDRIDGE, D.J. (2001): Biological Soil Crusts: Ecology and Management: TR-1730-2. US Department of the Interior Denver, CO, $110 \mathrm{pp}$.

Bergman, B. (2001): Nitrogen-fixing cyanobacteria in tropical oceans, with emphasis on the Western Indian Ocean. South African Journal of Botany 67: 426-432.

BerRendero Gómez, E.B.; Johansen, J.R.; KašTovskÝ, J.; BOHUNICKÁ, M. \& ČAPKOvÁ, K. (2016): Macrochaete gen. nov. (Nostocales, Cyanobacteria), a taxon morphologically and molecularly distinct from Calothrix. - Journal of Phycology, 52: 638-655.

BLÁHA, L.; BABICA, P. \& MARŠÁLEK, B. (2009): Toxins produced in cyanobacteria water blooms - toxicity and risks. Interdisciplinary Toxicology 2: 36-41.

Bonilla, S.; GonZÁles-Piana, M.; SoARes, M.C.S.; HusZar, V.L.M.; Becker. V.; Somma. A.; Marinho. M.M.; KoKociński. M.; DokUlil, M.; ANTONIADES, D. \& Aubriot, L. (2016): The success of the cyanobacterium Cylindrospermopsis raciborskii in freshwaters is enhanced by the combined effects of light intensity and temperature. - Journal of Limnology 75: 606-617.

BOyer, S.L.; FleChTNER, V.R. \& JOHANSEN, J.R. (2001): Is the 16S-23S rRNA internal transcribed spacer region a good tool for use in molecular systematics and population genetics? A case study in cyanobacteria. - Molecular Biology and Evolution 18: 1057-1069.

Branco, C.W.C. \& Senna, P.A.C. (1994): Factors influencing the development of Cylindrospermopsis raciborskii and Microcystis aeruginosa in the Paranoá reservoir, Brasília, Brazil. - Algological Studies 75: 85-96.

Breinlinger, S.; Phillips, T.J.; Haram, B.N.; Mareš, J.; Martínez Yerena, J.A.; HrouzeK, P.; SobotKa, R.; Henderson, W.M.; Schmieder, P.; Williams,
S.M.; Lauderdale, J.D.; WiLde, H.D.; Gerrin, W.; Kust, A.; Washington, J.W.; Wagner, C.; Geier, B.; LiebeKe, M.; ENKe, H.; NiedeRMEYeR, T.H.J. \& WiLdE, S.B. (2021): Hunting the eagle killer: A cyanobacterial neurotoxin causes vacuolar myelinopathy. - Science 371, eaax 9050

Briand, J.F.; Leboulanger, C.; Humbert, J.F.; Bernard, C. \& Dufour, P. (2004): Cylindrospermopsis raciborskii (Cyanobacteria) invasion at mid-latitudes: selection, wide physiological tolerance, or global warming? Journal of Phycology 40: 231-238.

Brohman, L. \& CARdillo, M. (2003): Testing the link between the latitudinal gradient in species richness and rates of molecular evolution. - Journal of Evolutionary Biology, 16: 200-207.

Brown, A.; Romanis, C.; Dvořák, P.; Foss, A.J.; Gibson, Q.A.; Villanueva, C.D.; Durden, W.N.; Garvey, A.D.; Jenkins, P.; HašLER, P.; JohANSEN, J.R.; NeILAN, B.A.; CASAmatTA, D.A. (2021): A cryptic and potentially toxigenic cyanobacterium isolated from the epidermis of a bottlenose dolphin and as a bioaerosol. - Phycologia (submitted).

Büdel, B.; Weber, B.; KüHl, M.; Pfanz, H.; SÜltmeyer, D. \& Wessels, D. (2002): Reshaping of sandstone surfaces by cryptoendolithic cyanobacteria: bioalkalization causes chemical weathering in arid landscapes. - Geobiology 2: 261-268.

CAI, F.; LI, X.; GenG, R.; Peng, Z. \& LI, R. (2019): Phylogenetically distant clade of Nostoc-like taxa with the description of Minunostoc gen. nov. and Minunostoc cylindricum sp. nov. - Fottea 19: 13-24

CAI, F.F. \& LI, R.H. (2020a): Purpureonostoc, a new name for a recently described genus of Nostoc-like cyanobacteria. - Fottea 20: 111

CAI, F.; PenG, X. \& LI, R. (2020b): Violetonostoc minutum gen. et sp. nov. (Nostocales, Cyanobacteria) from a rocky substrate in China. - Algae 35: 1-15.

Caires, T.A,; Sant'Anna, C.L. \& Nunes, J.M. (2019): Capilliphycus gen. nov.; validation of "Capillus T.A.Caires, Sant'Anna \& J.M.Nunes," inval. (Oscillatoriaceae, Cyanobacteria). - Notulae Algarum 95: 1-2.

Caires, T.A.; Lyra, G.M.; HentschKe, G.S.; Pedrini, A.G.; SANT'ANNA, C.L. \& Nunes, J.M.C. (2018): Neolyngbya gen. nov. (Cyanobacteria, Oscillatoriaceae): A new filamentous benthic marine taxon widely distributed along the Brazilian coast. - Molecular Phylogenetics and Evolution 120: 196-211.

Capelli, C.; Ballot, A.; Cerasino, L.; Papini, A. \& Salmaso, N. (2017): Biogeography of bloom-forming microcystin producing and non-toxigenic populations of Dolichospermum Lemmermannii (Cyanobacteria). - Harmful Algae 67: 1-12.

Capone, D.G.; Burns, J.A.; Montoya, J.P.; Subramaniam, A.; Mahaffey, A.C.; Gunderson, T.; Michaels, A.F. \& CARPENTER, E.J. (2005): Nitrogen fixation by Trichodesmium spp. an important source of new nitrogen to the tropical and subtropical North Atlantic Ocean. - Global Biogeochemical Cycles 19: GB2024.

CARo-Quintero, A. \& Konstantinidis, K.T. (2012): Bacterial species may exist, metagenomics reveal. - Environmental Microbiology 14: 347-355.

Casamatta, D.A.; Vis, M.L. \& Sheath, R.G. (2003): Cryptic species in cyanobacterial systematics: a case study of Phormidium retzii (Oscillatoriales) using 16S rDNA and RAPD analyses. - Aquatic Botany 77: 295-309. 
Casamatta, D.A.; Johansen, J.R.; Vis, M.L. \& Broadwater, S.T. (2005): Molecular and morphological characterization of ten polar and near-polar strains within the Oscillatoriales (Cyanobacteria). - Journal of Phycology 41: 421-438.

Casamatta, D.A.; Gomez, S.R. \& Johansen, J.R. (2006): Rexia erecta gen. et sp. nov. and Capsosira lowei $\mathrm{sp}$ nov., two newly described cyanobacteria taxa form the Great Smoky Mountains National Park (USA). Hydrobiologia 561: 13-26.

Casamatta, D.A.; Stanić, D.; Gantar, M. \& Richardson, L.L. (2012): Characterization of Roseonema reptotaenium (Oscillatoriales, Cyanobacteria) gen. et sp. nov. isolated from Caribbean black band disease. - Phycologia 51: 489-499.

Casamatta, D.A.; Villanueva, C.D.; Garvey, A.D.; Stocks, H.S.; VACCARINo, M.; DvořáK, P.; HaŠLER, P. \& Johansen, J.R. (2020): Reptodigitus chapmanii (Nostocales, Hapalosiphonaceae) gen. nov.: A unique nostocalean (Cyanobacteria) genus based on polyphasic approach. - Journal of Phycology 56: 425-436.

Castenholz, R.W. (2001): General characteristics of the Cyanobacteria. - In: Boone, D.R. \& CASTEnholz, R.W. (eds): Bergey's Manual of Systematic Bacteriology, vol. 1. - pp. 474-487, Springer, New York.

CASTenholz, R.W. \& NorRis, T.B. (2005): Revisionary concepts of species in the Cyanobacteria and their applications - Archiv für Hydrobiologie Supplement 159:53-69.

Cellamare, M.; de Tezanos, P.P.; Leitão, M.; Coste, M.; Boutry, S. \& HAURY, J. (2013): Using functional approaches to study phytoplankton communities in a temperate region exposed to tropical species dispersal. - Hydrobiologia 702: 267-282.

Charpy, L.; Palinska, K.A.; Casareto, B.; Langlade, M.J.; Suzuki, Y.; Abed, R.M.M. \& Golubic, S. (2010). Dinitrogen-fixing cyanobacteria in microbial mats of two shallow coral reef ecosystems. - Microbial Ecology 59: 174-186.

Chakraborty, S.; Maruthanayagam, V.; Achari, A.; Pramanik, A.; Parasuraman, J. \& MukherJee, J. (2019): Euryhalinema mangrovii gen. nov., sp. nov. and Leptoelongatus litoralis gen. nov., sp. nov. (Leptolyngbyaceae) isolated from an Indian mangrove forest. - Phytotaxa 422: 58-74

Charpy, L.; Casarero, B.E.; Langlade, M.J. \& Suzuki, Y. (2012): Cyanobacteria in coral reef ecosystems: a review. - Journal of Marine Biology, ID 259571:1-9.

Cellamare, M.; Duval C.; Drelin, Y.; Duediat, C.; Toibi, N.; Agogué, H.; Leboulanger, C.; Ader, M. \& BERNARD, C. (2018): Characterization of phototrophic microorganisms and description of new cyanobacteria isolated from the saline-alkaline crater-lake Dziani Dzaha (Mayotte, Indian Ocean). - FEMS Microbiology Ecology 94: 1-25.

Dadheech, P.K.; Casamatta, D.A.; Casper, P. \& Krienitz, L. (2013): A novel cyanobacterium Phormidium etoshii sp. nov. (Oscillatoriales) from the Etosha Pan, Namibia, based on morphological, molecular and ecological features. - Fottea 13: 235-244.

DesiKaChaRY, T.V. (1959): Cyanophyta. - In: RandHAWA, M.S. (ed.): Monographs on Algae. - 686pp., I.C.A.R. Indian Council of Agricultural Research, New Delhi.

Díez, B.; Bauer, K. \& Bergman, B. (2007): Epilithic cyanobacterial communities of a marine tropical beach rock (Heron Island, Great Barrier Reef): Diversity and
Diazotrophy. -Applied and Environmental Microbiology 73: $3656-3668$

Dittmann, E.; Fewer, D.P. \& Neilan, B.A. (2013): Cyanobacterial toxins: biosynthetic routes and evolutionary roots. FEMS Microbiology Reviews 37: 23-43.

Drouet, F. (1968): Revision of the classification of the Oscillatoriaceae. -370 pp., Monographs of the Academy of Natural Sciences, Philadelphia.

Drouet, F. (1973). Revision of the Nostocaceae with cylindrical trichomes. - 292 pp., Hafner Press. New York, USA.

Dvořák, P.; Casamatta, D.A.; Hašler, P.; OndřEJ, V.; PoulíčKová, A. \& SANGes, R. (2014): Synechococcus: 3 billion years of global dominance. - Molecular Ecology 23: 5538-5551.

DVOŘÁK, P. \& HAŠLER, P. (2007): Occurrence and morphological variability of Cylindrospermopsis raciborskii (Wolosz.) Seenayya et Subba Raju (Cyanophyta, Nostocales) near Olomouc in 2006. - Fottea 7: 39-42.

DvoŘÁK, P.; HAŠLER, P. \& PoulíčKová, A. (2012): Phylogeography of the Microcoleus vaginatus (cyanobacteria) from three continents - a spatial and temporal characterization. - PLoS ONE 7: e40153.

DvořÁk, P.; JahodéŘová, E.; CASAMATTA, D.A.; HašLER, P. \& POULÍČKOVÁ, A. (2018): Difference without distinction? Gaps in cyanobacterial systematics; when more is just too much. - Fottea 18:130-136.

Dvořák, P.; JAhodÁŘová, E.; HašLER, P.; GuSEv, E. \& PoulíčKoví, A. (2015a): A new tropical cyanobacterium Pinocchia polymorpha gen. et sp. nov. derived from genus Pseudanabaena. - Fottea 15: 113-120.

Dvořák, P.; PoulíčKová, A.; Hašler, P.; Belli, M.; Casamatta, D.A. \& PAPINI, A. (2015b): Species concepts and speciation factors in cyanobacteria, with connection to the problems of diversity and classification. - Biodiversity and Conservation 24: 739-757.

DvoŘÁk, P.; HašLER, P.; Pitelková P.; TABáková, P.; CasamatTA, D.A. \& PoulíčKová, A. (2017): A new cyanobacterium from the Everglades, Florida - Chamaethrix gen. nov. -Fottea 17: 269-276.

DvořÁK, P.; HašLeR, P. \& PoulíčKovÁ, A. (2020): New insights into the genomic evolution of cyanobacteria using herbarium exsiccate. - European Journal of Phycology 55: 30-38.

Dyble, J.; Paerl, H.W. \& Neilan, B. (2002): Genetic characterization of Cylindrospermopsis raciborskii (Cyanobacteria) isolates from diverse geographical origins based on nifH and cpcBA-IGS nucleotide sequence analysis. - Applied and Environmental Microbiology 68: 2567-2571.

ELDRIDGE, D.J. (2001): Biological soil crust of Australia. - In: Belnap, J., Lange, O.L. (eds): Biological Soil Crusts: Structure, Function and Management. - pp. 119-131, Springer: Berlin.

Engene, N.; Choi, H.; Esquenazi, E.; Rottacker, E.C.; Ellisman, M.H.; Dorrestein, P.C., \& Gerwick, W.H. (2011): Underestimated biodiversity as a major explanation for the perceived prolific secondary metabolite capacity of the cyanobacterial genus Lyngbya. -Environmental Microbiology 13: 1601-1610.

Engene, N.; RotTacker, E.C.; ChOI, H.; Byrum, T.; KaštovskÝ, J.H.; KomÁrek, J.; Ellisman, M. H. \& Gerwick, W.H. (2012): Moorea producta gen. nov., sp. nov. and Moorea bouillonii comb. nov., tropical marine cyanobacteria rich in bioactive secondary metabolites. - International Journal of Systematic and Evolutionary Microbiology 
62: $1172-1179$.

Engene, N.; Gunasekera, S.P.; Gerwick,W.H. \& Paul, V.J. (2013a): Phylogenetic inferences reveal large extent of novel biodiversity in chemically rich tropical marine cyanobacteria. - Applied and Environmental Microbiology 79: 1882-1888.

Engene, N.; Byrum, T.; Thor, A.; Ellisman, M.H.; Gerwick, W.H. \& PAUL, V.J. (2013b): Five chemically rich species of tropical marine cyanobacteria of the genus Okeania gen. nov. (Oscillatoriales, Cyanobacteria). - Journal of Phycology 49: 1095-1106.

Engene, N.; Tronholm, A.; SAlvador-Reyes, L.A.; Luesch, H. \& PAul, V.J. (2015): Caldora penicillata gen nov., sp. nov. (Cyanobacteria), a pantropical marine species with biomedical relevance. - Journal of Phycology 51: 670-681

Engene, N.; Tronholm, A. \& Paul, V.J. (2018): Uncovering cryptic diversity of Lyngbya: the new tropical marine cyanobacterial genus Dapis (Oscillatoriales). - Journal of Phycology 54:435-446.

Evans, K.L.; WARREN, P.H. \& GASTON, K.J. (2005): Species-energy relationships at the macroecological scale: a review of the mechanisms. - Biological Reviews 80: 1-25.

FALKowski, P. (2012): The power of plankton. Do tiny floating microorganisms in the ocean's surface waters play a massive role in controlling the global climate? - Nature 483: 17-20.

FINLAY, B.J. (2002): Global dispersal of free-living microbial eukaryote species. - Science 296: 1061-1063.

Fiore, M.F.; SANT'AnNA, C.L.; AzEVEdo, M.T.P.; KomÁREK, J.; KaŠTovskÝ, J.; SuleK, J. \& LoRenZI, A.S. (2007): The cyanobacterial genus Brasilonema, gen. nov., a molecular and phenotypic evaluation. - Journal of Phycology 43: 789-98.

Flechtner, V.R.; Boyer, S.L.; Johansen, J.R. \& DeNoble, M. (2002): Spirorestris rafaelensis gen. et sp. nov. (Cyanophyceae), a new cyanobacterial genus form arid soils. - Nova Hedwigia 74: 1-24.

Fleming, E.D. \& CAstenholz, R.W. (2007): Effects of periodic desiccation on the synthesis of the UV-screening compounds, scytonemin, in cyanobacteria. - Environmental Microbiology 9: 1448-1455.

FréMy, P. (1930): Les Myxophycées de 1'Afrique équatoriale francaise. - Archives de Botanique 2: 1-508.

Fuhrman, J.A.; Steele, J.A.; Hewson, I.; Schwalbach, M.S.; Brown, M.V.; GreEN, J.L. \& Brown, J.H. (2008): A latitudinal diversity gradient in planktonic marine bacteria. -Proceedings of the National Academy of Sciences of the United States of America 105: 7774-7778.

Gama, W.A.; Rigonata, J.; Fiore, M.F. \& SAnT'AnNa, C.L. (2019): New insights into Chroococcus (Cyanobacteria) and two related genera: Cryptococcum gen. nov. and Inacoccus gen. nov. - European Journal of Phycology 54: 315-325.

Garcia-Pichel, F.; Belnap, J.; Neuer, S. \& Schanz, F. (2003): Estimates of global cyanobacterial biomass and its distribution. - Algological Studies 109: 213-237.

Gardner, N.L. (1927): New Myxophyceae from Porto Rico. - In: Howe M.A.(ed.): Memoirs of The New York Botanical Garden, Vol. VII. - 144 pp., The New York Botanical Garden, New York.

Genuário, D.B.; De SouZa, W.R.; Monteiro, R.T.R.; SAnT'AnNA, C.L. \& Melo, I.S. (2020): Erratum: Amazoninema gen. nov. (Synechococcales, Pseudanabaenaceae) a novel cyanobacteria genus from Brazilian Amazonian rivers.
- International Journal of Systematic and Evolutionary Microbiology 70: 1441-1442.

Genuário, D.B.; Vieira Vaz, M.G.M.; HentschKe, G.S.; SANT'AnNA, C.L. \& Fiore, M.F. (2015): Halotia gen. nov., a phylogenetically and physiologically coherent cyanobacterial genus isolated from marine coastal environments. - International Journal of Systematic and Evolutionary Microbiology 65: 663-675.

Gillooly, J.F.; Allen, A.P.; West, B.G. \& Brown, J.H. (2005): The rate of DNA evolution: effects of body size and temperature on the molecular clock. - Proceedings of the National Academy of Sciences of the United States of America 102: 140-145.

Gold-Morgan, M.; Montejano, G. \& Komárek, J. (1994): Fresh-Water epiphytic cyanoprokaryotes form central Mexico. 2. Heterogeneity of the genus Xenococcus. Archiv fur Protistenkunde 143: 237-247.

GonZÁlez-Resendiz, L.; JohANSEn, J.R.; Alba-Lois, L.; Segal-KischinevZKy, C.; Escobar-SÁmche, V.; JiMÉNEZ-GARCía, L.F.; HuAER, T. \& LEÓN-TEJERA, H. (2018): Nunduva, a new marine genus of Rivulariaceae (Nostocales, Cyanobacteria) from marine rocky shores. - Fottea 18: 86-105.

Gruber, N. (2008): The marine nitrogen cycle: overview and challenges. - In: CAPONE, D.G., CARPENTER, E.J., BRonK, D.A. \& Mulholland, M.R. (eds): Nitrogen in the Marine Environment. - 49 pp., Academic Press and Elsevier, Burlington.

Gugger, M.; Molica, R.; Le Berre, B.; Dufour, P.; Bernard, D. \& Humbert, J.F. (2005): Genetic diversity of Cylindrospermopsis strains (Cyanobacteria) isolate from four Continents. - Applied and Environmental Microbiology 71: 1097-1100.

HaAnde, S.; Rohrlack, T.; Ballot, A.; RoberG, K.; SKulberG, R.; BeCK, M.; Wiedner, C. (2008): Genetic characterization of Cylindrospermopsis raciborskii (Nostocales, Cyanobacteria) isolates from Africa and Europe. - Harmful Algae 7: 692-701.

Hašler, P.; Casamatta, D.; Dvořák, P. \& PoulíčKová, A. (2017): Jacksonvillea apiculata (Oscillatoriales, Cyanobacteria) gen. \& sp. nov.: a new genus of filamentous, epipsamic cyanobacteria from North Florida. - Phycologia 56: 284-295.

HAŠLER, P.; DVOŘÁK, P.; ONDŘEJ, V.; KITNER, M.; HLOUŠKOVÁ , P. \& Poulíč́oví, A. (2011): The importance of the polyphasic approach in a comparative study of Nodularia Mertens ex Bornet et Flahault (Nostocales, Cyanobacteria). - Preslia 83: 167-182.

HAŠLER, P., DVOŘÁK, P.; JOHANSEN, J.R.; KiTNER, M.; ONDŘEJ, V. \& PoulíčKová, A. (2012): Morphological and molecular study of epipelic filamentous genera Phormidium, Microcoleus and Geitlerinema (Oscillatoriales, Cyanophyta/Cyanobacteria). - Fottea 12: 341-358.

HašLER, P.; DVořÁK, P. \& PoulíčKová, A. (2014a): A new genus of filamentous epipelic cyanobacteria, Johansenia. Preslia 86: 81-94.

Hašler, P.; Dvořák, P.; PoulíčKová, A. \& Casamatta, D.A. (2014b): A novel genus Ammassolinea gen.nov. (Cyanobacteria) isolated from subtropical epipelic habitats. - Fottea 14: 241-248.

HAŠLER, P. \& PoulíčKové, A. (2003): Diurnal changes in vertical distribution and morphology of a natural populations of Planktothrix agardhii (Gom.) Anagnostidis et Komárek (Cyanobacteria). - Hydrobiologia 506-509: 195-201.

Hauer, T.; BohunickÁ, M. \& Mühlsteinová, R. (2013): 
Calochaete gen.nov. (Cyanobacteria, Nostocales) a new cyanobacterial ty from the "páramo" zone in Costa Rica. - Phytotaxa 109: 36-44.

Heidari, F.; Zima, J. JR.; Riahi, H. \& Hauer, T. (2018): New simple trichal cyanobacterial taxa isolated from radioactive thermal springs. - Fottea 18: 137-149.

HenRy, J. (2005): Tropical and equatorial climates. - In: OLIVER, J.E., (ed): The encyclopedia of world climatology. 742-749 pp., Springer Dordrecht, Berlin, Heidelberg, New York.

Hentschke, G.S.; Johansen, J.R.; Pietrasiak, N.; Fiore, M. DE F., Rigonato, J., Sant'Anna, C.L. \& KomáreK, J. (2016): Phylogenetic placement of Dapisostemon gen. nov. and Streptostemon, two tropical heterocytous genera (Cyanobacteria). - Phytotaxa 245: 129-143.

Hentschke, G.S.; Johansen, J.R.; Pietrasiak, N.; Rigonato, J.; Fiore, M.F.; SANT'AnNA, C.L.(2017): Komarekiella atlantica gen. et sp. nov. (Nostocaceae, Cyanobacteria): a new subaerial taxon from the Atlantic Rainforest and Kauai, Hawaii. - Fottea 17: 178-190.

Hillebrand, H. (2004): On the generality of the latitudinal diversity gradient. - American Naturalist 163: 192-211.

Hoffmann, L. (1999): Marine cyanobacteria in tropical regions: diversity and ecology. - European Journal of Phycology 34: 371-379.

HoICZYK, E. (2000): Gliding motility in cyanobacteria: observations and possible explanations. - Archiv fur Microbiology 174: 11-17.

Horner-Devine, M.C.; CARney, K.M. \& Bohannan, B.J.M. (2004): An ecological perspective on bacterial biodiversity. - Proceedings of the Royal Society B 271: $113-122$.

Huisman, J.; Matthiss, H.C.P. \& VisSER, P.M. (2005): Harmful cyanobacteria. -243 pp., Springer publisher, Dodrecht.

Ionescu, D.; Hindiyeh, M.; MalKawi, H. \& ORen, A. (2010): Biogeography of thermophilic cyanobacteria: insights from the Zerka Ma'in hot springs (Jordan). - FEMS Microbial Ecology 72: 103-113.

Iteman, I.; Rippka, R.; Tandeau de Marsac, N. \& Herdman, M. (2000): Comparison of conserved structural and regulatory domains within divergent $16 \mathrm{~S}$ rRNA-23S rRNA spacer sequences of cyanobacteria. - Microbiology 146: $1275-1286$

JAHODÁŘová, E.; DvoŘÁK, P.; HaŠLER, P. \& PoulíčKová, A. (2017): Revealing hidden diversity among tropical cyanobacteria: the new genus Onodrimia (Synechococcales, Cyanobacteria) described using the polyphasic approach. - Phytotaxa 326: 28-40.

JAHODÁŘovÁ, E.; DVoŘÁK, P.; HAŠLER, P.; Holušová, K. \& PoulíčKovÁ, A. (2018): Elainella gen. nov.: a new tropical cyanobacterium characterized using a complex genomic approach. - European Journal of Phycology 53: 39-51.

JohANSEN, J.R. (1993): Crytogamic crusts of semiarid and arid lands of North America. -Journal of Phycology 29: $140-147$.

Johansen, J.R. \& Casamatta, D.A. (2005): Recognizing cyanobacterial diversity through adoption of a new species paradigm. - Algological Studies 117: 71-93.

Johansen, J.R.; Mareš, J.; Pietrasiak, N.; BohunickÁ, M.; ZimA, J. JR.; ŠTenCLOvÁ, L. \& HAUER, T. (2017): Highly divergent 16S rRNA sequences in ribosomal operons of Scytonema hyalinum (Cyanobacteria). - PLoS ONE 12: $\mathrm{e} 0186393$.

KASting, J. \& Siefert, J.L.(2002): Life and evolution of the earth's atmosphere. - Science 296: 1066-1068.

Kenoe, D.M. (2010): Chromatic adaptation and the evolution of light color sensing in cyanobacteria. - Proceedings of the National Academy of Sciences of the United States of America 107: 9029-9030.

Keshari, N. \& AdHIKarY, S.P. (2014): Diversity of cyanobacteria on stone monuments and building facades of India and their phylogenetic analysis. - International Biodeterioration \& Biodegradation 90: 45-51.

Kindlmann, P.; Schödelbauerová, I. \& Dixon, A.G. (2007): Inverse latitudinal gradients in species diversity. - In: Storch, D., Marquet, P.A. \& Brown, J.H. (eds): Scaling Biodiversity. - pp. 246-257, Cambridge University Press, Cambridge.

KLING, H.J. (2009): Cylindrospermopsis raciborskii (Nostocales, Cyanobacteria): A brief historic overview and recent discovery in the Assiniboine River (Canada). - Fottea 9: 45-47.

KoMÁREK, J. (1985): Do all cyanophytes have a cosmopolitan distribution? Survey of the freshwater cyanophyte flora of Cuba. - Algological Studies 38/39: 359-386.

KomÁREK, J. (2010): Recent changes (2008) in cyanobacteria taxonomy based on a combination of molecular background with phenotype and ecological consequences (genus and species concept). - Hydrobiologia 639: 245-259.

KomÁREK, J. (2011): Introduction to the $18^{\text {th }}$ IAC Symposium in České Budějovice 2010, Czech Republic. Some current problems of modern cyanobacterial taxonomy. - Fottea 11: 1-7.

KomÁreK, J. (2013): Cyanoprokaryota. 3. Heterocytous genera. - In: BÜDEL, B.; GÄRTNER, G.; KRIENITZ, L. \& SChagerl, M. (eds): Süswasserflora von Mitteleuropa/Freshwater flora of Central Europe, Vol. 19/3. - 1130 pp., Springer SpektrumBerlin, Heidelberg.

KomÁReK, J. (2018): Several problems of the polyphasic approach in the modern cyanobacterial system. Hydrobiologia 811:7-17.

KomÁREK J. (2020): Quo vadis, taxonomy of cyanobacteria (2019). - Fottea 20: 104-110.

KomÁreK, J. \& ANAGNOSTIDIS, K. (1998): Cyanoprokaryota1. Chroococcales. - In: EtTL, H.; GäRTNER, G.; HeYNIG, H.\& Mollenhauer, D. (eds): Süsswasserflora von Mitteleuropa, Vol. 19/1. - 548 pp., Gustav Fischer, Jena-Stuttgart-Lübeck-Ulm.

KomÁREK, J. \& ANAGNOSTIDIS, K. (2005): Cyanoprokaryota 2. Oscillatoriales. - In: BÜDEL, B.; KRIENITZ, L.; GÄRTNER, G. \& SCHAGERL, M. (eds): Süsswasserflora von Mitteleuropa, Vol. 19/2. - 759 pp., Elsevier/ Spektrum, Heidelberg.

KomÁrek, J. \& HindÁK, F. (1975): Taxonomy of the new isolated strains of Chroococcidiopsis (Cyanophyceae). - Algological Studies 13: 311-329.

KomÁreK, J.; KAŠtovsKÝ, J.; MAReš, J. \& JohanSEn. J.R. (2014). Taxonomic classification of cyanoprokaryotes (cyanobacterial genera) 2014 using a polyphasic approach. - Preslia 86: 295-335.

KomÁreK, J. \& KomÁRKovÁ-Legnerová, J. (2002): Contribution to the knowledge of planktic cyanoprokaryotes from central Mexico. - Preslia 74: 207-233.

KomÁReK, J. \& KomáRkoví-Legnerová, J. (2007): Several rare freshwater planktic Cyanobacteria (Cyanoprokaryotes) from reservoirs in South America. - Hoehnea 34: 49-58.

KomÁreK, J.; KomÁrKová, J.; VeNTURA, S.; KoZLíKová-ZaPOMĚLová, 
E. \& RejmánKová, E. (2017): Taxonomic evaluation of cyanobacterial microflora from alkaline marshes of northern Belize. 3. Diversity of heterocytous genera. - Nova Hedwigia 105: 445-486.

KomÁreK, J.; ZapomĚlová, E.; Šmarda, J., ReJMÁnKovÁ, E.; Woodhouse, J.; Neilan, B.A. \& Komárková, J. (2013a): Polyphasic evaluation of Limnoraphis robusta, a water -bloom forming cyanobacterium from Lake Atitlán, Guatemala, with a description of Limnoraphis gen. nov. - Fottea 13: 39-52.

KomÁrek, J.; Sant'Anna, C.; BohunickÁ, M.; Mareš, J.; HentschKe, G.S., Rigonato, J. \& Fiore, M. (2013b): Phenotype diversity and phylogeny of selected Scytonemaspecies from SE Brazil. - Fottea 13: 173-200.

Komárková, J.; ZAPOMĚlová, E. \& KomÁreK, J. (2013): Chakia (cyanobacteria), a new heterocytous genus from Belizean marshes identified on the basis of the 16S rRNA gene. - Fottea 13: 227-233

Krienitz, L.; Dadheech, P.K. \& Kotut, K. (2013): Mass developments of a small sized ecotype of Arthrospira fusiformis in Lake Oloidien, Kenya, a new feeding ground for lesser flamingos in East Africa. - Fottea 13: $215-225$.

LAMPrinou, V.; HeRnÁndeZ-Mariné, M.; PACHIADAKi, M.G.; Kormas, K.A.; ECONOMOU-Amilli, A. \& PantaZidou, A. (2013): New findings on the true-branched monotypic genus Iphinoe (Cyanobacteria) from geographically isolated caves (Greece). - Fottea 13: 15-23.

LemeS-DA-Silva, N.M.; BRANCO, L.H. \& NeCChI, JR. O. (2012): Corticolous cyanobacteria from tropical forest remnants in northwestern São Paulo State, Brazil. - Brazilian Journal of Botany 35: 169-179.

Lesser, M.P.; Mazel, Ch.H.; Gorbunov, M.Y. \& Falkowski, P.G. (2004): Discovery of symbiotic nitrogen-fixing cyanobacteria in Corals. - Science 305: 997-1000.

LI, Z. (2009): Advances in marine symbiotic cyanobacteria. In: Gault, P.M. \& Marler, H.J. (eds): Handbook on Cyanobacteria. - pp. 463-472, Nova Science Publisher, Hauppauge.

Lozupone, C.A. \& KNight, R. (2007): Global patterns in bacterial diversity. - Proceedings of the National Academy of Sciences of the United States of America 104: 11436-11440.

Lukešová, A.; Johansen, J.R.; Martin, M. \& CASAmatta, D.A. (2009): Aulosira bohemensis sp. nov.: Further uncertainty at the base of the Nostocales (Cyanobacteria). -Phycologia 48: 118-129.

Lyons, T.W.; Reinhard, C.T. \& Planavsky, N.J. (2014): The rise of oxygen in Earth's early ocean and atmosphere. - Nature 506: 307-315.

Mai, T.; Johansen, J.R., Pietrasiak, N.; Bohunická, M. \& Martin, M.P. (2018): Revision of the Synechococcales (Cyanobacteria) through recognition of four families including Oculatellaceae fam. nov. and Trichocoleaceae fam. nov. and six new genera containing 14 species. - Phytotaxa 365: 1-59.

Malone, C.F.S; Rigonato, J.; Laughinghouse, H.D.; Schmidt, É.C.; Bouzon, Z.L.; Wilmotte, A.; Fiore, M.F. \& SAnT'AnnA, C.L. (2015): Cephalothrix gen. nov. (Cyanobacteria): towards an intraspecific phylogenetic evaluation by multilocus analyses. - International Journal of Systematic and Evolutionary Microbiology 69: 2993-3007.

Mannion, P.D.; Upchurch, P.; Benson, R.B.J. \& Goswami, A. (2014): The latitudinal biodiversity gradient through deep time. - Trends in Ecology and Evolution 29: 42-50.

MAREŠ, J. (2018): Multilocus and SSU r RNA gene phylogenetic analyses of available cyanobacterial genomes, and their relation to the current taxonomic system. - Hydrobiologia 811:19-34.

Mareš, J.; Johansen, J.R.; Hauer, T.; Zima, J.; Ventura, S., Cuzman, O.; TiRibilli, B. \& KAŠTOvsKÝ, J. (2019): Taxonomic resolution of the genus Cyanothece (Chroococcales, Cyanobacteria), with a treatment on Gloeothece and three new genera Crocosphaera, Rippkaea and Zehria. - Journal of Phycology 55: 578-610.

Martins, M.D. \& Branco, L.H.Z. (2016): Potamolinea gen. nov. (Oscillatoriales, Cyanobacteria): a phylogenetically and ecologically coherent cyanobacterial genus. - International Journal of Systematic and Evolutionary Microbiology 66: 3632-3641.

Martins, M.D.; Rigonato, J.; TABOGa, S.R.; BranCo, L.H.Z. (2016): Proposal of Ancylothrix gen. nov., a new genus of Phormidiaceae (Cyanobacteria, Oscillatoriales) based on a polyphasic approach. - International Journal of Systematic and Evolutionary Microbiology 66: 2396-2405.

Martins, M.D.; Machado-DE-Lima, N.M. \& BranCo, L.H.Z. (2018): Polyphasic approach using multilocus analyses supports the establishment of the new aerophytic cyanobacterial genus Pycnacronema (Coleofacisculaceae, Oscillatoriales). - Journal of Phycology 55: 146-159

Matteo, P.; Legane's, F.; Perona, E. \& Loza, V. (2015): Cyanobacteria as bioindicators and bioreporters of environmental analysis in aquatic ecosystems. Biodiversity and Conservation 24: 909-948.

Mazard, S.; Ostrowski, M.; Partensky, F.; Scanian, D.J. (2012): Multi-locus sequence analysis taxonomic resolution and biogeography of marine Synechococcus. - Environmental Microbiology 14: 372-386.

Mazard, S.; Penesyan, A.; Ostrowski, M.; Paulsen, I.T. \& EgAN, S. (2016): Tiny Microbes with a big impact: The role of cyanobacteria and their metabolites in shaping our future. - Marine Drugs 14: 97.

Meeks, J.C. (1998): Symbiosis between nitrogen-fixing cyanobacteria and plants. - BioScience 48: 266-276.

Mehnert, G.; Leunert, F.; CirÉs, S.; JÖHNK, K.D.; RÜCKer, J.; Nixdorf, B. \& Wiedner, C. (2010): Competitiveness of invasive and native cyanobacteria from temperate freshwaters under various light and temperature conditions. - Journal of Plankton Research 32: 1009-1021.

McGregor, G.B. \& Sendall, B.C. (2017a): Ewamiania thermalis gen. et sp. nov. (Cyanobacteria, Scytonemataceae), a new cyanobacterium from Talaroo thermal springs, north-eastern Australia. - Australian Systematic Botany 30: 38-47.

McGREGOR, G.B. \& SENDALl, B.C. (2017b): Iningainema pulvinus gen nov., sp nov. (Cyanobacteria, Scytonemataceae) a new nodularin producer from Edgbaston Reserve, north-eastern Australia. - Harmful Algae 62: 10-19.

Mcgregor, G.B. \& Sendall, B.C. (2019): Potamosiphon australiensis gen. nov., sp nov. (Oscillatoriales), a new filamentous cyanobacterium from subtropical north-eastern Australia. - Phytotaxa 387: 77-93.

Miscoe, L.H.; JohANSEn, J.R.; KocioleK, J.P.; Lowe, R.L.; Vaccarino, M.A.; Pietrasiak, N. \& Sherwood, A.R. (2016): The diatom flora and cyanobacteria from caves on Kauai, Hawaii. - In: KIES, L. \& SCHNETTER, R. (eds): Bibliotheca Phycologica 120. - 152 pp., J. Cramer in 
Borntraeger Science Publishers, Stuttgart.

Miscoe, L.H.; Johansen, J.R.; VACCARInO, M.A.; Pietrasiak, N. \& SHeRwood, A.R. (2016): The diatom flora and cyanobacteria from caves on Kauai, Hawaii. II. Novel cyanobacteria from caves on Kauai, Hawaii. - In: KIES, L. \& Schnetter, R. (eds): Bibliotheca Phycologica 123. - pp. 75-152, J. Cramer in Borntraeger Science Publishers, Stuttgart.

Mittelbach, G.G.; Schemske, D.W.; Cornell, H.V.; Allen, A.P.; Brown, J.M.; Bush, M.B.; Harrson, S.P.; Hurlbert, A.H.; Knowlton, N.; Lessios, H.A.; McCain, C.M.; McCune, A.R.; McDade, L.A.; McPeeK, M.A.; Near, T.J.; Price, T.D.; Ricklefs, R.E.; Kaustuv, R.; Sax, D.F.; Schulter, D., Sobel, J.M. \& Turelli, M. (2007): Evolution and the latitudinal diversity gradient: speciation, extinction and biogeography. - Ecology Letters 10: 325-331.

Moisander, P.H.; BeInart, R.A.; Hewson, I.; White, A.E.; Johnson, K.S.; CARLSON, C.A.; Montoya, J.P. \& ZeHR, J.P. (2010): Unicellular cyanobacterial distributions broaden the oceanic N2 fixation domain. - Science 327: $1512-1514$.

MonteguaRdo, J.L.M. (2016): Benthic freshwater cyanobacteria as indicators of anthropogenic pressures. - Ecological Indicators 67: 693-702.

Montejano, G.; Gold, M. \& KomÁReK, J. (1993): Freshwater epiphytic cyanoprocaryotes from Central Mexico I. Cyanocystis and Xenococcus. - Archiv für Protistenkunde 143: 237-247.

Montejano, G.; Gold-Morgan, M. \& KomáReK, J. (1997): Epiphytic Chroococcales (cyanoprokaryota) of the central region of Mexico. - Phycologia 36: 73.

Moreira, C.; Fathalli, A.; Vasconcelos, V. \& Antunes, A. (2011): Genetic diversity and structure of the invasive toxic cyanobacterium Cylindrospermopsis raciborskii. - Current Microbiology 62: 1590-1595.

Moreira, C.; Spillane, Ch.; Fathalli, A.; Vasconcelos, V. \& Antunes, A. (2014): African Origin and EuropeMediated Global Dispersal of the cyanobacterium Microcystis aeruginosa. - Current Microbiology 69: 628-633.

Moreira, D.; Tavera R.; Benzerara, K.; Skouri-Panet, F.; Couradeau, E.; Loussert Fonta, C.; Novelo, E.; ZIVANOVIC, Y. \& LÓPEZ-GARCÍA, P. (2017): Description of Gloeomargarita lithophora gen. nov., sp. nov., a thylakoid-bearing basal-branching cyanobacterium with intracellular carbonates, and proposal for Gloeomargaritales ord. nov. - International Journal of Systematic and Evolutionary Microbiology 67: 653-658.

Moreira, C.; Vasconcelos, V. \& Antunes, A. (2013): Phylogeny and Biogeography of Cyanobacteria and their produced toxins. - Marine Drugs II: 350-4369.

Mowe, M.A.D.; Mitrovic, S.M.; Lim, R.P., Furey, A. \& Yeo, D.C.J. (2015): Tropical cyanobacterial blooms: a review of prevalence, problem taxa, toxins and influencing environmental factors. - Journal of Limnology 74:205-224.

Nabout, J.C.; DA Silva Rocha, B.; CARneIro, F.M. \& SAnT'AnNa, C.L. (2013): How many species of Cyanobacteria are there? Using a discovery curve to predict the species number. - Biodiversity and Conservation 22: 2907-2918.

NASElli-Flores, L. \& PADisÁK, J. (2016): Blowing in the wind: how many roads can a phytoplankton walk down? A synthesis on phytoplankton biogeography and spatial processes. - Hydrobiologia 764: 303-313.
NeustupA, J. \& ŠKAlOUd, P. (2008): Diversity of subaerial algae and cyanobacteria on tree bark in tropical mountain habitats. - Biologia 63: 806-812.

NGuYen, X.H.; Sumimoto, S. \& SudA, S. (2017): Unexpected high diversity of terrestrial cyanobacteria from the campus of the University of the Ryukyus, Okinawa, Japan. -Microorganisms 5: 69.

Nowicka-KrawczyK, P.; MüHLsteinová, R. \& Hauer, T. (2019): Detailed characterization of the Arthrospira type species separating commercially grown taxa into the new genus Limnospira (Cyanobacteria). - Scientific Reports 9: 1-11.

NüBel, U.; GarCiA-PiChel, F. \& MuYzer, G. (2008): PCR primers to amplify $16 \mathrm{~S}$ rRNA genes form cyanobacteria. - Applied and Environmental Microbiology 63: 3327-3332.

Nweze, N.O. (2009): Ecological implications and roles of cyanobacteria (Cyanophyta) in food security - a review. - Plant Product Research Journal 13:8-14.

Oren, A. (2011): Naming Cyanophyta/Cyanobacteria-a bacteriologist's view. - Fottea 11: 9-16.

Oren, A. \& Garrity, G.M. (2014): Proposal to change general consideration 5 and principle 2 of the international code of nomenclature of prokaryotes. - International Journal of Systematic and Evolutionary Microbiology 64: 309-310.

Oren, A. \& Ventura, S. (2017): The current status of cyanobacterial nomenclature under the "prokaryotic" and the "botanical" code. - Antonie van Leeuwenhoek 110: 1257-1269.

Ortega-Morales, B.O.; Novelo, E.; Ramírez, M. \& Gaylarde, C.C. (2006): Cyanobacterial diversity and ecology on historic monuments in Latin America. - Revista Latinoamericana de Microbiología 48: 88-195.

Osorio-Santos, K.; Pietrasiak, N.; BohunickÁ, M.; Miscoe, L.H.; KovéčIK, L.; Martin, M.P. \& Johansen, J.R. (2014): Seven new species of Oculatella (Pseudanabaenales, Cyanobacteria). - European Journal of Phycology 49: 450-470.

PADIsÁk, J. (1997): Cylindrospermopsis raciborskii (Woloszynska) Seenayya et Subba Raju, an expanding, highly adaptive cyanobacterium: worldwide distribution and review of its ecology. - Archive für Hydrobiologie Supplement 107: 563-93.

Palińska, K.A.; Abed, R.M.M.; Wendt, K.; Charpy, L.; LOTOCKA, M. \& Golubić, S. (2012): Opportunistic cyanobacteria in benthic microbial mats of a tropical lagoon, Tikehau Atoll, Tuamotu Archipelago: minor in natural populations, major in cultures. - Fottea 12: $127-140$.

Palinska, K.A. \& Surosz, W. (2014): Taxonomy of cyanobacteria: a contribution to consensus approach. - Hydrobiologia 740: 1-11.

PaPke, R.T.; RAmsing, N.; Bateson, M.M. \& Ward, D.M. (2003): Geographical isolation in hot spring cyanobacteria. - Environmental Microbiology 5: 650-659.

PASSY, S.I. (2010): A distinct latitudinal gradient of diatom diversity is linked to resource supply. - Ecology 91: 36-41.

Pearl, H.W. \& Huisman, J. (2009): Climate change: a catalyst for global expansion of harmful cyanobacterial blooms. - Environmental Microbiology Reports 1: 27-37.

Pearl, H.W. \& Paul, V.J. (2012): Climate change: links to global expansion of harmful cyanobacteria. - Water Research 46: 1349-1363.

PAERL, H. (2017): The cyanobacterial nitrogen fixation paradox 
in natural waters. - F1000Research 6:244.

Pedersen, D. \& Miller, S.R. (2017): Photosynthetic temperature adaptation during niche diversification of the thermophilic cyanobacterium Synechococcus A/B clade. - ISME Journal 11: 1053-1057.

Perkerson, R.B.; Johansen, J.R.; KováčIK, L.; Brand, J.; KaštovskÝ, J. \& CASAMATTA, D.A. (2011): A unique Pseudanabaenalean (Cyanobacteria) genus Nodosilinea gen. nov. based on morphological and molecular data. - Journal of Phycology 47: 1397-1412.

Pietrasiak, N.; Osorio-Santos, K.; Shalygin, S.; Martin, M.P. \& JohANSEN, J.R. (2019): When is a lineage a species? A case study in Myxacorys gen. nov. (Synechococcales: Cyanobacteria) With the description of two new species from the Americas. - Journal of Phycology 55: 976-996.

PoulíčKová, A.; Dvořák, P.; MaZalová, P. \& Hašler, P. (2014): Epipelic microphototrophs: an overlooked assemblage in lake ecosystems. - Freshwater Science 33: 513-523.

PoulíčKová, A.; HašLER, P. \& Kitner, M. (2004): Annual cycle of Planktothrix agardhii (Gom.) Anagn. \& Kom. nature population. - International Review of Hydrobiology 89:278-288.

Quiblier, C.; Wood, S.; Echenique-Subiabre, I.; Heath, M.; Villeneuve, A. \& Humbert, J.F. (2013): A review of current knowledge on toxic benthic freshwater cyanobacteria - ecology, toxin production and risk management. - Water Research 47: 5464-5479.

Ramírez, M.; HernÁndeZ-MarinÉ, M.; Mateo, P.; BerRendero, E. \& Roldán, M. (2011): Polyphasic approach and adaptive strategies of Nostoc cf. commune (Nostocales, Nostocaceae) on Mayan monuments. - Fottea 11: 73-86.

RAI, A.N.; BERgMAN, B. \& RASMuSSEN, U. (2002): Cyanobacteria in symbiosis. -355 pp., Kluwer Academic Publishers, Boston.

R CoRe TeAm (2020): R: A language and environment for statistical computing. R Foundation for Statistical Computing, Vienna, Austria. URL http://www.R-project.org/

Ribeiro, K.F.; Ferrero, A.P.; Duarte, L.; Turchetto-Zolet, A.C. \& CrossetTi, L.O. (2020): Comparative phylogeography of two free-living cosmopolitan cyanobacteria: insights on biogeography and latitudinal distribution. - Journal of Biogeography 47: 1106-1118.

Rigonato, J.; Arantes Gama, W.; Oliverira, D.; Zanini Branco, L.H.; Pereira Brandini, F.; Genuário, D.B. \& Fiore, M.F. (2016): Aliterella atlantica gen. nov., sp. nov., and Aliterella antarctica sp. nov., novel members of coccoid Cyanobacteria. -International Journal of Systematic and Evolutionary Microbiology 66: 2853-2861.

Rigonato, J.; Sant'Anna, C.; Giami, A.; Azevedo, M.T.P.; Gama, W.A.; Viana, V.F.L.; Fiore, M.F. \& Werner, V.R. (2018): Sphaerocavum: a coccoid morphogenus identical to Microcystis in terms of $16 \mathrm{~S}$ rDNA and ITS sequence phylogenies. - Hydrobiologia 811: 35-48.

Rippka, R.; Deruelles, J.; Waterbury, J.B.; Herdmann, M. \& STANIER, R.Y. (1979): Generic assignments, strain histories, and properties of pure cultures of cyanobacteria. -Journal General Microbiology 111: 1-61.

Rocap, G.; Larimer, F.W.; Lamerdin, J.; Malfatti, S.; Chain, P.; Ahlgren, N.A.; Arellano, A.; Coleman, M.; Hauser, L.; Hess, W.R.; Johnson, Z.I.; LAND, M.; Lindell, D.; Post, A.F.; Regala, W.; Shah, M.; Shaw, S.L.; Steglich, C.; Sullivan. M.B.; Ting, C.S.; Tolonen, A.; Webb, E.A.; Zinser, E.R. \&
Chisholm, S.W. (2003): Genome divergence in two Prochlorococcus ecotypes reflects oceanic niche differentiation. - Nature 424: 1042-1047.

SAha, R.: Verseput, A.T.: Berla, B.M.: Mueller, TJ. \& Pakrasi, H.B. (2012): Reconstruction and Comparison of the Metabolic Potential of Cyanobacteria Cyanothece sp. ATCC 51142 and Synechocystis sp. PCC 6803. - PLoS ONE 7: e48285. doi:10.1371/journal.pone.0048285

Sant'Anna, C.L.; Gama, W.A.; Rigonato, J.; Correa, G. \& MARINHO, M.M. (2018 ('2019')): Phylogenetic connection among close genera of Aphanizomenonaceae (Cyanobacteria): Amphiheterocytum gen. nov., Cylindrospermopsis and Sphaerospermopsis. - Algal Research 37: 205-214.

SANT'AnNA, C.L.; AzEvedo, T.M.P.; KAŠTOvSKÝ, J. \& KoMÁREK, J. (2010): Two form-genera of aerophytic heterocytous cyanobacteria from Brazilian rainy forest „Mata Atlântica". - Fottea 10: 217-228.

Sant'AnNa, C.L.; Watson, A.G.JR.; Azevedo, M.T.P \& KomÁREK, J. (2011): New morphospecies of Chamaesiphon (Cyanobacteria) from Atlantic rainforest Brazil. Fottea 11: 25-30.

SARAF, A.G.; Dawda, H.G. \& Singh, P. (2019a): Validation of the genus Desikacharya gen. nov. (Nostocaceae, Cyanobacteria) and three included species. - Notulae Algarum 107: 1-3.

Saraf, A.; SuradKar, A.; Dawda, H.G.; Gaysina, L.A.; Gabidullin, Y.; Kumat, A.; Behere, I.; Kotulkar, M.; Batule, P. \& Singh, P. (2019b): Phylogenetic complexities of the members of Rivulariaceae with the re-creation of the family Calotrichaceae and description of Dulcicalothrix necridiiformans gen nov., sp nov., and reclassification of Calothrix desertica. - FEMS Microbiology Letters 366: fnz219

ŠEBela, M.; JAHODÁŘ́VÁ, E.; RAUS, M.; LENOBEL, R. \& HAŠLER, P. (2018): Intact cell MALDI-TOF mass spectrometric analysis of Chroococcidiopsis cyanobacteria for classification purposes and identification of possible marker proteins. - PloS One 13: e0208275.

Shalygin, S.; Huang, I.-S.; Allen, E. H.; Burkholder, J. M., \& ZIMBA, P. V. (2019): Odorella benthonica gen. \& sp. nov. (Pleurocapsales, Cyanobacteria): an odor and prolific toxin producer isolated from a California aqueduct. - Journal of Phycology 55: 509-520.

Sherwood, A.R.; Carlile, A.L.; Vaccario, M.A. \& Johansen, J.R. (2015): Characterization of Hawaiian freshwater and terrestrial cyanobacteria reveals high diversity and numerous putative endemics. - Phycological Research 63: 85-92.

SChIRRMeIster, B.E.; GugGer, M. \& Donoghue, P.C.J. (2015): Cyanobacteria and the great oxidation event: Evidence from genes and fossils. - Paleontology 58: 769-785.

Schopf, J.W. (2000): The fossil record: tracing the roots of the cyanobacterial lineages. - In: Whitton, B.A. \& PotTs, M. (eds): The ecology of cyanobacteria: Their diversity in time and space. - pp. 13-35, Springer, Berlin.

Siegesmund, M.A.; Johansen, J.R.; Karsten, U. \& Friedl, T. (2008): Coleofasciculus gen. nov. (Cyanobacteria): Morphological and molecular criteria for revision of the genus Microcoleus Gomont. - Journal of Phycology 44: $1572-1585$.

Sili, C.; Mascalchi, C. \& Ventura, S. (2011): Evolutionary differentiation of the sister cyanobacterial genera Cyanospira and Anabaenopsis in response to extreme life conditions. - Fottea 11: 107-117. 
Sinetova, M.A.; Bolatkhan, K.; Sidorov, R.A.; Mironov, K.S.; SKryPNIK, A.N.; KuPRIYANOVA, E.V.; ZaYAdAN, B.K.; ShumsKaYa, M. \& Los, D.A. (2017): Polyphasic characterization of the thermotolerant cyanobacterium Desertifilum sp. Strain IPPAS B-1220. - FEMS Microbiology Letters 364: fnx027

Singh, R.K.; Tiwari, S.P.; Ashwani, K.R. \& Mohapatra. T.M. (2011): Cyanobacteria: an emerging source for drug discovery. - Journal of Antibiotics 64: 401-412.

SoININEN, J. (2012): Macroecology of unicellular organisms patterns and processes. - Environmental Microbiology Reports 4: 10-22.

Spiller, H. \& Shanmugam, K.T. (1987): Physiological conditions for nitrogen fixation in a unicellular marine cyanobacterium, Synechococcus sp. strain SF1. - Journal of Bacteriology 169: 5379-5384.

Stanic, D.; Oehrie, S.; Gantar, M. \& Richardson, L.L. (2010): Microcystin production and ecological physiology of Caribbean black band disease cyanobacteria. - Environmental Microbiology 13: 900-910.

Stomp, M.; Huisman, J.; Mittelbach, G.G.; Litchman, E. \& KLAusmeier, C.A. (2011): Large-scale biodiversity patterns in freshwater phytoplankton. - Ecology 92: 2096-2107.

SukeniK, A.; Hadas, O.; KaPlan, A. \& Quesada, A. (2012): Invasion of Nostocales (Cyanobacteria) to subtropical and temperate freshwater lakes- Physiological, regional and global driving forces. - Frontiers in Microbiology 3: 86.

Tamames, J.; Abellan, J.J.; Pignatelli, M.; Camacho, A. \& Moya, A. (2010): Environmental distribution of prokaryotic taxa. - BMC Microbiology 10: 85.

Tawong, W.; Pongcharoen, P.; Pongradung, P. \& Ponza, S. (2019); Neowollea manoromense gen. \& sp. nov. (Nostocales, Cyanobacteria), a novel geosmin producer isolated from Thailand. - Phytotaxa 421: 1-17.

Usher, K.M.; Bergman, B. \& Raven, J.A. (2007): Exploring cyanobacterial mutualisms. - Annual Review of Ecology, Evolution and Systematics 38: 255-73.

Uyeda, J.C.; Harmon, L.J. \& Blank, C.E. (2016): A comprehensive study of cyanobacterial morphological and ecological evolutionary dynamics through deep geologic time. - PLoS ONE 11: e0162539

VACCARINO, M.A. \& JOHANSEN, J.R. (2011): Scytonematopsis contorta sp. nov. (Nostocales), a new species from Hawaiian Islands. - Fottea 11: 149-161.

VACCARINO, M.A. \& JohANSEN, J.R. (2012): Brasilonema angustatum sp. nov (Nostocales), a new filamentous cyanobacterial species from the Hawaiian Islands. Journal of Phycology 48: 1178-1186.

Van Gremberghe, I.; Leliaert, F.; Mergeay, J.; Vanormelingen, P.; Van Der Gucht, K.; Debeer, A.; Lacerot, G.; De MEester, L. \& VyVerman, W. (2011): Lack of phylogeographic structure in the freshwater cyanobacterium Microcystis aeruginosa suggests global dispersal. - PloS ONE 6: e195651. DOI: 10.1371/journal.pone.0019561.

VieIra Vaz, M.G.; Genuário, D.B.; ANDreote, A.P.; Malone, C.F.; SANT'Anna C.L; BARbiero, L. \& Fiore, M.F. (2015): Pantanalinema gen. nov. and Alkalinema gen. nov.: novel pseudanabaenacean genera (Cyanobacteria) isolated from saline-alkaline lakes. -International Journal of Systematic and Evolutionary Microbiology 65: 298-308.

Villanueva, C.D.; Garvey, A.; Hašler, P.; Dvořák, P.; PoulíčKová, A.; Norwich, A.R. \& CASAMatTa, D.A (2019a): Descriptions of Brasilonema geniculatum and Calothrix dumus (Nostocales, Cyanobacteria): two new taxa isolated from cemetery tombstones. Phytotaxa 387: 1-20

Villanueva, C.D.; Hašler P.; Dvořák, P.; PoulíčKová, A. \& Casamatta, D.A. (2019b): Brasilonema lichenoides sp. nov. and Chroococcidiopsis lichenoides sp. nov. (Cyanobacteria): two novel cyanobacterial constituents isolated from a tripartite lichen of headstones. - Journal of Phycology 54: 224-233.

WANG, Y.; CAI, F.; JiA, N. \& LI, R. (2019): Description of a novel coccoid cyanobacterial genus and species Sinocapsa zengkensis gen. nov. sp. nov. (Sinocapsaceae, incertae sedis), with taxonomic notes on genera in Chroococcidiopsidales. - Phytotaxa, 409: 146-160.

Warren-Rhodes, K.A.; Rhodes, K.L.; Pointing, S.B.; Ewing, S.A.; LACAP, D.C.; GómEZ-Silva, B.; AMUNDSON, R.; Friedmann, E.I. \& McKaY, Ch.P. (2006): Hypolithic cyanobacteria, dry limit of photosynthesis, and microbial ecology in the hyperarid Atacama Desert. - Microbial Ecology 52: 389-398.

Wilde, S. B.; Johansen, J. R.; Wilde, H. D.; Jiang, P.; Bartelme, B. A. \& HaYnie, R. S. (2014): Aetokthonos hydrillicola gen. et sp. nov.: epiphytic cyanobacteria on invasive aquatic plants implicated in Avian Vacuolar Myelinopathy. - Phytotaxa 181: 243-60.

Whitaker, R.J.; Grogan, D.W. \& TAYlor, J.W. (2003): Geographic barriers isolate endemic populations of hyperthermophilic archaea. - Science 301: 976-978,

Whitton, B.A. \& Potts, M. (eds) (2000): The ecology of cyanobacteria: their diversity in time and space. -669 pp., Springer, Berlin.

Wilk-Woźniak, E.; Solarz, W.; NajBerek, K. \& Pociecha, A. (2016): Alien cyanobacteria: an unsolved part of the "expansion and evolution" jigsaw puzzle? Hydrobiologia 764: 65-79.

Wood, S.A.; Pochon, X.; LutTringer-Plu, L.; VAnt, B.N. \& HAMILTON, D.P. (2014): Recent invader or indicator of environmental change? A phylogenetic and ecological study of Cylindrospermopsis raciborskii in New Zealand. - Harmful Algae 39: 64-74.

Wright, S.; Keeling, J. \& Gillman, L. (2006): The road from Santa Rosalia: a faster tempo of evolution in tropical climates. - Proceedings of the National Academy of Sciences of the United States of America 103: 7718-7722.

ZAммIT, G. (2018): Systematics and biogeography of sciphilous cyanobacteria; an ecological and molecular description of Albertania skiophila (Leptolyngbyaceae) gen. \& sp. nov. - Phycologia 57: 481-491.

Zanchett, G. \& Oliveira-Filho, E.C. (2013): Cyanobacteria and cyanotoxins: from impacts on aquatic ecosystems and human health to anticarcinogenic effects. - Toxins 5: 1896-1917.

Zehr, J.P.; Bench, S.R.; Mondragon, E.A.; McCarren, J. \& DeLong, E.F. (2007): Low genomic diversity in tropical oceanic N2-fixing cyanobacteria. - Proceedings of the National Academy of Sciences of the United States of America 104: 17807-17812.

Zhou, W.G.; Ding, D.W.; YANG, Q.S.; AhMAD, M.; Zhang, Y.Z.; Lin, X.CH.; Zhang, Y.Y.; LinG, J. \& Dong, J.D. (2018): Marileptolyngbya sina gen. nov., sp. nov. and Salileptolyngbya diazotrophicum gen. nov., sp. nov. (Synechococcales, Cyanobacteria), species of cyanobacteria isolated from a marine ecosystem. Phytotaxa 383: 75-92. 
Zimba, P.V.; HuANG, I.S.; Foley, J.E. \& Linton, E.W. (2017): Identification of a new-to-science cyanobacterium, Toxifilum mysidocida gen. nov. \& sp. nov. (Cyanobacteria, Cyanophyceae). - Journal of Phycology 53: 188-197.

Zimba, P.V.; Shalygin, S.; Huang, I.-S.; MomČIlović, M. \& AbDula, H. (2020): A new boring toxin producer Perforafilum tunnelli gen. \& sp. nov. (Oscillatoriales, Cyanobacteria) isolated from Laguna Madre, Texas, USA. - Phycologia 60: 10-24.

Zwirglmaier, K.; Heywood, J.L.; Chamberlain, K.; Woodward, E.M.S.; ZubKov, M.V. \& Scanlan, D.J. (2007): Basin scale distribution patterns of picocyanobacterial lineages in the Atlantic Ocean. - Environmental Microbiology
9: $1278-1290$.

Zwirglmaier, K.; Jardillier, L.; Ostrowski, M.; MaZard, S.; GarcZareK, L.; Vaulot, D.; Not, F.; Massana, R.; UlLOA, O. \& SCANLAN, D.J. (2008): Global phylogeography of marine Synechococcus and Prochlorococcus reveals a distinct partitioning of lineages among oceanic biomes. - Environmental Microbiology 10: 147-161.

(C) Czech Phycological Society (2021)

Received April 27, 2021

Accepted May 6, 2021 